\title{
Description and evaluation of a net energy intake model as a function of dietary chewing index
}

\author{
L. M. Jensen, ${ }^{* 1}$ B. Markussen,† N. I. Nielsen,‡ E. Nadeau,§ M. R. Weisbjerg,\# and P. Nørgaard* \\ *Department of Veterinary Clinical and Animal Science, Faculty of Health and Medical Sciences, and \\ †Laboratory of Applied Statistics, Department of Mathematical Sciences, Faculty of Science, University of Copenhagen, Universitetsparken 5, \\ 2100 Copenhagen, Denmark \\ ¥SEGES, Dairy and Beef Research Centre, Agro Food Park 15, 8200 Aarhus, Denmark \\ §Department of Animal Environment and Health, Swedish University of Agricultural Sciences, Box 234, 53223 Skara, Sweden \\ \#Department of Animal Science, AU Foulum, Faculty of Science and Technology, Aarhus University, Blichers Allé 20, 8830 Tjele, Denmark
}

\section{ABSTRACT}

Previously, a linear relationship has been found between net energy intake (NEI) and dietary chewing index (CI) of the diet for different types of cattle. Therefore, we propose to generalize and calibrate this relationship into a new model for direct prediction of NEI by dairy cows from $\mathrm{CI}$ values $\left(\mathrm{CI}_{\mathrm{NE}}\right.$; $\mathrm{min} / \mathrm{MJ}$ of $\left.\mathrm{NE}\right)$. Furthermore, we studied the forage-to-concentrate substitution rate in this new NEI model. To calibrate the model on a diverse set of situations, we built a database of mean intake from 14 production experiments with a total of 986 primi- and multiparous lactating dairy cows of different breeds fed 136 different diets ad libitum. The NEI were estimated by the Nordic feed evaluation system. The $\mathrm{CI}_{\mathrm{NE}}$ value of diets was estimated from the intake of concentrate, intake of forage neutral detergent fiber $\left(\mathrm{NDF}_{\mathrm{f}}\right)$, particle length of forage, indigestible $\mathrm{NDF}_{\mathrm{f}} / \mathrm{NDF}_{\mathrm{f}}$, body weight, $\mathrm{NDF}_{\mathrm{f}} /$ body weight, and the content of NE in DM. We show that the slope values in this regression are proportional to the squared intercepts, giving the nonlinear equation $\mathrm{NEI}=\mathrm{NEI}_{0}-k \times \mathrm{NEI}_{0}^{a} \times \mathrm{CI}_{\mathrm{NE}}$, where the parameter $k$ represents the decline in NEI with the increasing $\mathrm{CI}_{\mathrm{NE}}$ of the diet and $a$ was estimated to have a value of 2 , implying a constant maximum daily chewing time. The intercept $\mathrm{NEI}_{0}$ in the regression of $\mathrm{NEI}$ on $\mathrm{CI}_{\mathrm{NE}}$ may be interpreted as metabolic net energy intake capacity of the cows fed without physical constraints on intake. Based on experimental data, the maximum chewing time was estimated as $1 /(4 \times k)$. The $\mathrm{NEI}_{0}$ values were parameterized as a linear function of metabolic body size, energy-corrected milk yield $(\mathrm{kg} / \mathrm{d})$, days in milk, and days in milk squared. Prediction accuracy was evaluated by mean square prediction error (MSPE) and its decomposition into central tendency, regression, and

\footnotetext{
Received September 13, 2015.

Accepted July 14, 2016.

${ }^{1}$ Corresponding author: lauramie@sund.ku.dk
}

disturbance, across and within experiments on independent data from 19 experiments including 812 primi- and multiparous lactating dairy cows of different breeds fed 80 different diets ad libitum. The NEI model predicted NEI with an MSPE of $8 \%$ of observed, and across the 19 experiments the error central tendency, error regression, and error disturbance were $4.2,40.6$, and $84.9 \%$ of MSPE, respectively. The described intake model implies a variable forage-to-concentrate substitution rate as a nonlinear function of $\mathrm{NEI}_{0}, \mathrm{CI}_{\mathrm{NE}}$ of forage, and supplementation of concentrate.

Key words: intake capacity, maximum chewing time, substitution rate

\section{INTRODUCTION}

Performance and productivity of high-yielding dairy cows is closely linked to their energy intake (Friggens et al., 1995). Feed intake is driven by energy demands for maintenance, growth, milk production, and reproduction (Romney and Gill, 2000) and is controlled by an interaction between animal and dietary characteristics (Mertens, 2007). The dietary characteristics include the proportion of concentrate and forage characteristics, such as NDF concentration, digestibility of OM, physical form, DM content, and fermentation characteristics (Allen, 1996, 2000). Accurate predictions of voluntary feed intake are important in the formulation of optimal diets to support the productivity of cows (Allen, 1996). However, evaluations (Krizsan et al., 2014; Jensen et al., 2015a) of the NRC (2001), Zom et al. (2012), Gruber et al. (2004), TDMI (Huhtanen et al., 2011), and NorFor (Volden et al., 2011) models showed that these models all had a fairly high prediction error (SD) of 1.5 to $3 \mathrm{~kg}$ of $\mathrm{DMI} / \mathrm{d}$, and a systematic overprediction at high DMI and underprediction at low DMI. These discrepancies could be due to variable substitution rates between forages and concentrates depending on the energy balance and intake (Faverdin et al., 1991, 2011). Randby et al. (2012) found a quadratic increase in 
DMI at increasing concentrate intake, and interactions among forage quality and concentrate intake with week of lactation. In addition, a quadratic decreasing intake of forage NDF $\left(\mathbf{N D F}_{\mathrm{f}}\right)$ per BW was found at increasing concentrate supplementation (Randby et al., 2012). Feed intake is considered to be physically constrained by $\mathrm{NDF}_{\mathrm{f}}$ concentration of high-forage diets (Allen, 1996), with a maximum $\mathrm{NDF}_{\mathrm{f}}$ intake of 1.2 to $1.3 \%$ of BW (Mertens, 1994). Intake models generally predict DMI (Faverdin, 1992; Ingvartsen, 1994), which is associated with net energy intake (NEI). Nørgaard and Mølbak (2001) introduced an NEI model that implies a variable substitution rate depending on the degree of metabolic or physical constraint on intake, concentrate intake, and forage quality. The substitution rate varies between zero at high-forage diets with high $\mathrm{NDF}_{\mathrm{f}}$ per $\mathrm{BW}$ and -1 at high concentrate intake and low $\mathrm{NDF}_{\mathrm{f}}$ intakes (Jensen, 2015). The NEI model by Nørgaard and Mølbak (2001) describes a negative linear relationship between NEI and the corrected dietary chewing index value $\left[\mathbf{C I}_{\mathrm{NE}} ; \min / \mathrm{MJ}\right.$ of net energy $\left.(\mathbf{N E})\right]$ within experiments of lactating dairy cows, dry cows, growing bulls, and steers. The estimated intercept values $\left[\mathbf{N E I}_{0} ; \mathrm{MJ}\right.$ of $\mathrm{NE} / \mathrm{kg}$ of metabolic BW $\left.\left(\mathbf{B W}^{0.75}\right)\right]$ for the individual experimental group of cattle are interpreted as their metabolic NEI capacity when rumen fill approaches zero. The $\mathrm{NEI}_{0}$ of lactating cows, nonlactating cows, and growing cattle was shown to be $1.5 \pm$ $0.16,0.87 \pm 0.11$, and $0.83 \pm 0.11$, respectively. The objective of our study was to further develop and apply the NEI model described by Nørgaard and Mølbak (2001) by parameterization and evaluation on dairy cows fed different diets, and to demonstrate the variable substitution rate between forage and concentrates based on the model.

\section{MATERIALS AND METHODS}

\section{Modeling Data}

Relationships between the NEI of lactating dairy cows and the $\mathrm{CI}_{\mathrm{NE}}$ values of their diets were analyzed on intake data from 14 Nordic experiments, including a total of 136 treatment means using 986 lactating dairy cows (both primiparous and multiparous) at lactation stages ranging from 25 to 275 DIM (mean 114 DIM). The use of literature data hindered use of individual data. The cows were tied up or loose housed, and were fed TMR (66 treatment means) or forage ad libitum supplemented with restricted amounts of concentrate (70 treatment means). The breeds included were Norwegian Red (24 treatment means), Finnish Ayrshire (16 treatment means), Jersey (16 treatment means),
Table 1. Dry matter intake, net energy intake (NEI), and ECM yield of the 14 experiments expressed as mean, SD, minimum, and maximum $^{1}$

\begin{tabular}{lcrcc}
\hline Item & Mean & SD & Minimum & Maximum \\
\hline DMI (kg of DM/d) & 18.6 & 2.5 & 12.7 & 24.0 \\
NEI (MJ of NE/d) & 120 & 16.2 & 84.9 & 160 \\
ECM (kg/d) & 27.7 & 5.4 & 17.1 & 49.7 \\
\hline
\end{tabular}

${ }^{1}$ Data consist of 136 treatment means from 986 lactating dairy cows in 14 experiments conducted in Denmark, Finland, and Norway.

Danish Red (16 treatment means), and Danish Holstein (64 treatment means). The average BW of the treatment groups ranged from 415 to $706 \mathrm{~kg}$. The included experiments were retrieved from a Nordic database and both Latin square and continuous designs were represented. All experiments used were previously published studies conducted in Denmark, Finland, and Norway (Thuen, 1989; Aaes, 1993; Kristensen, 1999; Rinne et al., 1999; Lund, 2002; Randby, 2003; Schei et al., 2005; Nielsen et al., 2007; Weisbjerg, 2007; Kristensen and Weisbjerg, 2008; Prestløkken et al., 2008; Bossen et al., 2009; Weisbjerg et al., 2013). The mean, standard deviation, minimum, and maximum values of DMI, NEI, and ECM are presented in Table 1.

Forages used in the 14 indoor experiments included 23 grass and grass-clover silages, 2 alfalfa silages, 5 maize silages, 3 whole-crop silages, 1 alfalfa hay, 3 grass hays, and 3 treated or untreated straws, with a mean theoretical chopping length (TCL; mm) of 10 to 100 $\mathrm{mm}$ and a forage proportion of the diet DM ranging from 15 to $84 \%($ mean $=59.4, \mathrm{SD}=14.0)$. Table 2 presents mean and standard deviation of nutrient composition of the total diets and of the forage used in the experiments.

Table 2. Nutritional characteristics of the diets from 136 treatment means in 14 indoor experiments expressed as mean, SD, minimum, and maximum

\begin{tabular}{lcccc}
\hline Item & Mean & SD & Minimum & Maximum \\
\hline $\mathrm{OMD}^{1}(\%)$ & 75.0 & 2.56 & 65.5 & 81.7 \\
$\mathrm{CP}^{2}(\mathrm{~g} / \mathrm{kg}$ of DM) & 157 & 21.6 & 117 & 227 \\
$\mathrm{NDF}_{\mathrm{t}}{ }^{3}(\mathrm{~g} / \mathrm{kg}$ of DM) & 364 & 56.7 & 187 & 516 \\
$\mathrm{NDF}_{\mathrm{f}}{ }^{5}$ (g/kg of DM) & 471 & 103 & 269 & 761 \\
iNDF $_{\mathrm{t}}{ }^{\mathrm{t}}$ (g/kg of DM) & 71.7 & 19.0 & 33.8 & 133 \\
$\mathrm{CI}_{\mathrm{DM}}{ }^{6}(\mathrm{~min} / \mathrm{kg}$ of DM) & 39.6 & 8.90 & 19.0 & 62.6 \\
\hline
\end{tabular}

${ }^{1}$ Organic matter digestibility as percentage of diet OM.

${ }^{2}$ Crude protein concentration of diet DM.

${ }^{3}$ Neutral detergent fiber concentration of diet DM.

${ }^{4}$ Neutral detergent fiber concentration of forage DM.

${ }^{5}$ Indigestible neutral detergent fiber concentration of diet DM.

${ }^{6}$ NorFor chewing index of diet DM (Nørgaard et al., 2011). 


\section{Estimation of NE Value of the Diet}

In our study, the ME value of the diet consumed by groups of lactating dairy cows was estimated by the NorFor digestive model (Volden and Nielsen, 2011) from the predicted apparently digested $\mathrm{CP}$, crude fat, carbohydrates, and a correction for the content of sugar. The $\mathrm{NE}$ values of the diets were calculated from the ME values by using the NorFor digestive model, and are described as $\mathrm{NE}_{\mathrm{L}}$ in NorFor (Volden and Nielsen, 2011).

\section{Chewing Index of the Diet}

The chewing index, expressed as minutes per kilogram of DM ( $\left.\mathbf{C I}_{\mathbf{D M}}\right)$ of a feed in NorFor, is estimated as the sum of the eating index (EI; min $/ \mathrm{kg}$ of DM) and rumination index (RI; min $/ \mathrm{kg}$ of DM; Nørgaard et al., 2011). The use of a chewing index (CI) accounting for EI and RI to rank feeds by the fibrousness was proposed by Balch (1971). The time spent on mastication is used to quantitatively rank the biological fibrousness of the feeds (Nørgaard et al., 2011). The EI ( $\mathrm{min} / \mathrm{kg}$ of DM; equation 1) of a feed is proportional to its NDF concentration $(\mathrm{g} / \mathrm{kg})$ and its TCL $(\mathrm{mm}$; Nørgaard et al., 2010):

$$
\begin{gathered}
\mathrm{EI}=50 \times(\mathrm{NDF} / 1,000) \\
\times[1-0.52 \times \exp (-0.078 \times \mathrm{TCL})] .
\end{gathered}
$$

The RI ( $\mathrm{min} / \mathrm{kg}$ of DM; equation 2) of a feed is proportional to its NDF concentration $(\mathrm{g} / \mathrm{kg}$ of DM), its TCL $(\mathrm{mm})$, and a linear function of indigestible NDF $(\mathrm{g} / \mathrm{kg}$ of NDF; Nørgaard et al., 2011):

$$
\begin{gathered}
\mathrm{RI}=100 \times(\mathrm{NDF} / 1,000) \\
\times\{1-\exp [-0.173 \times(\mathrm{TCL} / 0.7-1)]\} \\
\times(0.75+\text { indigestible NDF } / \mathrm{NDF}) .
\end{gathered}
$$

The NorFor chewing index refers to the estimated chewing time per kilograms of DM in a standard cow of $625 \mathrm{~kg}$ of $\mathrm{BW}$, with an average intake of $\mathrm{NDF}_{\mathrm{f}}$ related to $B W$ of $0.007(\mathrm{~kg} / \mathrm{kg})$, and a daily rumination time of around 400 min (Nørgaard et al., 2011).

\section{Calculation of Corrected and Transformed Cl}

The $\mathrm{CI}_{\mathrm{DM}}(\mathrm{min} / \mathrm{kg}$ of $\mathrm{DM})$ was corrected to the actual mean $\mathrm{BW}$ and intake of $\mathrm{NDF}_{\mathrm{f}}$ in the individual treatments according to Nørgaard et al. (2010), as shown in equation 3 :

$$
\begin{aligned}
\mathrm{CI}_{\mathrm{DM}}= & {\left[\mathrm{EI}+\mathrm{RI}+\left(0.007-\mathrm{NDF}_{\mathrm{f}} / \mathrm{BW}\right) \times 52\right.} \\
& \left.\times \mathrm{NDF}_{\mathrm{f}} / \mathrm{DMI}\right] \times(625 / \mathrm{BW}) .
\end{aligned}
$$

The $\mathrm{CI}_{\mathrm{DM}}$ values were transformed into $\mathrm{CI}_{\mathrm{NE}}$ (expressed as min/MJ of $\mathrm{NE}$ ) by dividing $\mathrm{CI}_{\mathrm{DM}}$ with the energy density (MJ of NE/kg DM) of the mixed ration. The dietary $\mathrm{CI}_{\mathrm{NE}}$ value represents a combined index of both the reciprocal energy density (DM/NE) and concentration of $\mathrm{NDF}_{\mathrm{f}}$ adjusted for physical form and hardness of NDF (Nørgaard et al., 2011).

\section{Description of the NEI Model}

Nørgaard and Mølbak (2001) found a linear relationship between the NEI (MJ of NE/day) and the $\mathrm{CI}_{\mathrm{NE}}$ of the consumed diet (equation 4), where the $\mathrm{CI}_{\mathrm{DM}}$ value was calculated based on standard chewing index values estimated from concentration of crude fiber content and DM according to Nørgaard (1986), transformed into minutes per NE by dividing by the net energy density of the total diet (MJ of NE/ $\mathrm{kg}$ of DM):

$$
\mathrm{NEI}=\mathrm{NEI}_{0}-b \times \mathrm{CI}_{\mathrm{NE}} .
$$

When the linear relationship (equation 4) is used for an individual cow, the intercept $\mathrm{NEI}_{0}$ can be interpreted as the metabolic NEI capacity when intake is not limited by rumen fill. The slope $b\left[(\mathrm{MJ} \text { of } \mathrm{NE} / \mathrm{d})^{2} /(\mathrm{min} / \mathrm{d})\right]$ in equation 4 describes the linear decrease in NEI with increasing corrected $\mathrm{CI}_{\mathrm{NE}}$ value of the diet.

Rearranging equation 4 , the $\mathrm{CI}_{\mathrm{NE}}$ may be expressed as $\mathrm{CI}_{\mathrm{NE}}=\left(\mathrm{NEI}_{0}-\mathrm{NEI}\right) / b$. The daily chewing time $(\mathbf{C T} ; \mathrm{min} / \mathrm{d})$ can be expressed as the amount of energy consumed per day multiplied by the $\mathrm{CI}_{\mathrm{NE}}$ of the consumed diet, which implies $\mathrm{CT}=\mathrm{NEI} \times \mathrm{CI}_{\mathrm{NE}}=$ $\mathrm{NEI} \times\left(\mathrm{NEI}_{0}-\mathrm{NEI}\right) / b$. For an individual cow with intake characteristics described by $\mathrm{NEI}_{0}$ and $b$, the CT is a quadratic polynomial in the NEI, and it attains its maximum $\left(\mathbf{C T}_{\max }\right)$ as $\mathrm{CT}_{\max }=\left(\mathrm{NEI}_{0}\right)^{2} /(4 \times b)$, when $\mathrm{NEI}=1 / 2 \times \mathrm{NEI}_{0}$. This relationship implies that the slope $b=\left(\mathrm{NEI}_{0}\right)^{2} /\left(4 \times \mathrm{CT}_{\text {max }}\right)$ may be expressed in terms of $\mathrm{NEI}_{0}$ and $\mathrm{CT}_{\max }$. Substituting this expression for $b$ into equation 4 results in

$$
\mathrm{NEI}=\mathrm{NEI}_{0}-\frac{\left(\mathrm{NEI}_{0}\right)^{2}}{4 \times \mathrm{CT}_{\max }} \times \mathrm{CI}_{\mathrm{NE}} .
$$

The equation for $\mathrm{CT}=\mathrm{NEI} \times \mathrm{CI}_{\mathrm{NE}}$ implies that $\mathrm{CT}$ approaches $\mathrm{CT}_{\max }$ at increasing $\mathrm{CI}_{\mathrm{NE}}$ value toward $\mathrm{CT}_{\max } /\left(1 / 2 \times \mathrm{NEI}_{0}\right)$ and decreasing NEI toward $1 / 2 \times$ $\mathrm{NEI}_{0}$. Equation 5 will only be used for $\mathrm{CI}_{\mathrm{NE}}<\mathrm{CT}_{\max } /$ $\left(1 / 2 \times \mathrm{NEI}_{0}\right)$; that is, for NEI $>1 / 2 \times \mathrm{NEI}_{0}$. Equation 5 namely implies that $\mathrm{CT}$ decreases with increasing $\mathrm{CI}_{\mathrm{NE}}$ if used for $\mathrm{CI}_{\mathrm{NE}}>\mathrm{CT}_{\max } /\left(1 / 2 \times \mathrm{NEI}_{0}\right)$, which is biologically meaningless. Net energy intakes higher that $1 / 2 \times \mathrm{NEI}_{0}$ are considered to be partly metabolic 
and partly physically constrained, and below $1 / 2 \times$ $\mathrm{NEI}_{0}$ intakes are considered to be mainly physically constrained by the capacity of the digestive tract. The intercept value $\left(\mathrm{NEI}_{0}\right)$ of equation 5 is a prediction of the metabolic net energy intake capacity $\left(\mathrm{NEI}_{0}\right)$ of the animal.

\section{Maximum CT}

The mathematical arguments deriving equation 5 from equation 4 allow the $\mathrm{CT}_{\max }$ to vary among cows. However, in empirical fits of the parameters $\mathrm{NE}_{0}$ and $b$ from several experiments, Nørgaard and Mølbak (2001) observed a direct proportionality between $b$ and $\left(\mathrm{NEI}_{0}\right)^{2}$ in terms of a universal constant $k$. Such a relationship implies that $\mathrm{CT}_{\max }=\left(\mathrm{NEI}_{0}\right)^{2} /(4 \times b)=1 /(4 \times k)$ is constant. To verify the direct proportionality found by Nørgaard and Mølbak (2001), the present study generalizes the relation between the slope $b$ and the $\mathrm{NEI}_{0}$ to the power shown in equation 6 , and seeks to study whether the exponent $a$ can be assumed to be equal to 2 :

$$
b=k \times\left(\mathrm{NEI}_{0}\right)^{a} .
$$

\section{Linear Modeling of $\mathrm{NEI}$ as a Function of $\mathrm{Cl}_{N E}$}

The linear relation between $\mathrm{NEI}$ and $\mathrm{CI}_{\mathrm{NE}}$ stated in equation 4 was fitted to the observations from the 136 treatment means. As the intercept and slope in equation 4 are assumed to be similar for genetically similar cows at a similar stage of lactation, a statistical model with random intercepts and slopes within experiments and within treatment means was used:

$$
\begin{aligned}
& \mathrm{NEI}_{i}=\mathrm{NEI}_{0}^{\text {fixed }}+\mathrm{NEI}_{0}^{\text {Exp }}\left(\operatorname{Exp}_{i}\right)+\mathrm{NEI}_{0, i}^{T M}- \\
& {\left[b^{\text {fixed }}+b^{E x p}\left(\operatorname{Exp}_{i}\right)+b_{i}^{T M}\right] \times \mathrm{CI}_{\mathrm{NE}, i}}
\end{aligned}
$$

where $i=1, \ldots, 136$ denotes the observation index; $\operatorname{Exp}_{i}$ denotes the experiment of the $i$ th observation, and $\left(\mathrm{NEI}_{0}^{\mathrm{fixed}}, b^{\text {fixed }}\right)$ are systematic effects describing the population mean. The random effects $\left[\operatorname{NEI}_{0}^{\operatorname{Exp}}\left(\operatorname{Exp}_{i}\right), b^{\operatorname{Exp}}\left(\operatorname{Exp}_{i}\right)\right]$ describe the biological variation between the $\operatorname{Exp}_{i}=1, \ldots, 14$ experiments, and the random effects $\left(\mathrm{NEI}_{0, i}^{T M}, b_{i}^{T M}\right)$ describe the biological variation between the $i=1, \ldots, 136$ treatment means $(T M)$. According to equation 6, the intercepts and slopes are expected to be related; hence, we allow for correlation within the components $\left[\mathrm{NEI}_{0}^{\operatorname{Exp}}\left(\operatorname{Exp}_{i}\right), b^{\operatorname{Exp}}\left(\operatorname{Exp}_{i}\right)\right]$ and $\left(\mathrm{NEI}_{0, i}^{T M}, b_{i}^{T M}\right)$. The statistical model [7] is a linear mixed effects models, where
$\mathrm{NEI}_{0, i}^{T M}$ usually would be interpreted as the error term; however, in [7] we interpret $\left(\mathrm{NEI}_{0, i}^{T M}, b_{i}^{T M}\right)$ as random intercepts and slopes on the individual observations in a model without error terms. Although such a model is rarely used, it is straightforward to fit this model using standard mixed effects model methods, and the random effects $\left[\mathrm{NEI}_{0}^{E x p}\left(\operatorname{Exp}_{i}\right), b^{\operatorname{Exp}}\left(\operatorname{Exp}_{i}\right)\right]$ and $\left(\mathrm{NEI}_{0, i}^{T M}, b_{i}^{T M}\right)$ can be used to predict the intercept and slope in equation 4 for the individual treatment means. Validation of the normality assumptions on the random terms in the statistical model [7] was done by normal quantile plots of the predictions of the random effects.

\section{Relationship Between Slope $\mathrm{b}$ and $\mathrm{NEI}_{0}$}

The power relation stated in equation 7 between the predicted slopes $b^{\text {fixed }}+b^{E x p}\left(\operatorname{Exp}_{i}\right)+b_{i}^{T M}$ and the intercepts $\mathrm{NEI}_{0}^{\mathrm{fixed}}+\mathrm{NEI}_{0}^{E x p}\left(\operatorname{Exp}_{i}\right)+\mathrm{NEI}_{0, i}^{T M}$ was estimated in a nonlinear regression model with the residual term, $\varepsilon_{\mathrm{i}}$ :

$$
\begin{aligned}
& b^{\mathrm{fixed}}+b^{E x p}\left(\operatorname{Exp}_{i}\right)+b_{i}^{T M}= \\
& k \times\left[N E I_{0}^{\mathrm{fixed}}+N E I_{0}^{E x p}\left(\operatorname{Exp}_{i}\right)+N E I_{0, i}^{T M}\right]^{a}+\varepsilon_{i} .
\end{aligned}
$$

The statistical model was validated by normal quantile and residual plots. Confidence intervals for the parameters $k$ and $a$ were found by profile likelihood. However, formal hypothesis tests were not done, as the correlation between the predictions of the random effects implies that the 136 observations of the slopes and intercepts cannot be considered as independent.

\section{Animal Characteristics as Variables in the $\mathrm{NEI}_{0}$}

The modeling data included animal characteristics such as breed, BW, observed milk yield, proportion of primiparous cows in the treatment groups, DIM, and calculated values of $\mathrm{BW}^{0.75}, \mathrm{ECM}$, and (DIM) ${ }^{2}$. Body weight and $\mathrm{BW}^{0.75}$ are interchangeable values, where BW is associated with the size of the cows, and therefore the volume of their guts (Demment and Van Soest, $1985)$, and $\mathrm{BW}^{0.75}$ is related to the energy requirements for maintenance (Conrad et al., 1964). Energy-corrected milk yield was calculated according to NorFor (Åkerlind et al., 2011), adapting the equations developed by Sjaunja et al. (1990):

$$
\begin{aligned}
\mathrm{ECM} & =\mathrm{MY} \times\left[0.01+0.122 \times\left(\mathrm{f} \_ \text {milk } / 10\right)+0.077\right. \\
& \left.\times\left(\mathrm{p} \_ \text {milk } / 10\right)+0.053 \times\left(\mathrm{l} \_ \text {milk } / 10\right)\right]
\end{aligned}
$$

and in case l_milk was not available 


$$
\begin{aligned}
\mathrm{ECM}= & \mathrm{MY} \times\left[0.25+0.122 \times\left(\mathrm{f} \_ \text {milk } / 10\right)\right. \\
& \left.+0.077 \times\left(\mathrm{p} \_ \text {milk } / 10\right)\right],
\end{aligned}
$$

where MY is the observed daily milk yield $(\mathrm{kg} / \mathrm{d})$, f_milk, p_milk, and l_milk are the contents of fat, protein, and lactose in the milk, respectively $(\mathrm{g} / \mathrm{kg})$.

\section{Parameterization of $\mathrm{NEI}_{0}$}

The NEI model (equation 5) demonstrates a linear relationship between NEI calculated in the NorFor digestive model as $\mathrm{NE}_{\mathrm{L}}$ (Volden and Nielsen, 2011) and $\mathrm{CI}_{\mathrm{NE}}$ values of the diets. The intercept $\mathrm{NEI}_{0}$ can be interpreted as the metabolic energy intake capacity of $\mathrm{NE}$ when intake is not constrained by rumen fill or $\mathrm{CT}_{\max }$.

By modeling the $\mathrm{NEI}_{0}$ in equation 5 as a function of animal characteristics, it is possible to predict $\mathrm{NEI}_{0}$ for each cow or group of cows depending on characteristics important for maintenance and production. This gives equation 9, where all the animal characteristics mentioned in previous section, except breed, were used in a linear model for $\mathrm{NEI}_{0}$ of the individual treatment means and were fitted by nonlinear least squares to the observations from the $i=1, \ldots, 136$ treatment means:

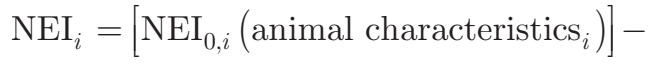

$$
\begin{aligned}
& \frac{\left[\mathrm{NEI}_{0, i}\left(\text { animal characteristics }_{i}\right)\right]^{2}}{4 \times \mathrm{CT}_{\max }} \times \mathrm{CI}_{\mathrm{NE}, i}+\varepsilon_{i} \text {. }
\end{aligned}
$$

Model reduction was performed for all animal characteristics and was kept in the model if the $P$-values were 0.05 or lower or if the characteristics were considered of high biological importance.

\section{Forage-to-Concentrate Energy Substitution Rate}

The forage-to-concentrate energy substitution rate can be estimated from equation 5 as a nonlinear dependency of $\mathrm{CI}_{\mathrm{NE}}, \mathrm{NEI}_{0}, \mathrm{CT}_{\max }$, and the allocated net energy from concentrate $\left(\mathbf{N E I}_{\mathbf{c}} ; \mathrm{MJ}\right.$ of $\left.\mathrm{NE} / \mathrm{d}\right)$. By assuming no energetic interaction between the NE value of forage (MJ of NE/ kg of DM) and NE of concentrate (MJ of NE/ $\mathrm{kg}$ of $\mathrm{DM}$ ), and no interaction between forage intake and the $\mathrm{CI}_{\mathrm{f}}$ value, the NEI is the sum of allocated $\mathrm{NEI}_{c}$ plus the intake of forage $\mathrm{NE}\left(\mathbf{N E I}_{\mathbf{f}} ; \mathrm{MJ}\right.$ $\mathrm{NE} / \mathrm{d}$ ) and expressed as

$$
\mathrm{NEI}=\mathrm{NEI}_{\mathrm{f}}+\mathrm{NEI}_{\mathrm{c}}
$$

The forage-to-concentrate energy substitution rate is expressed as the differential of $\mathrm{NEI}_{\mathrm{f}}$ with respect to
$\mathrm{NEI}_{\mathrm{c}}$. The $\mathrm{CI}_{\mathrm{NE}}$ value as described earlier can likewise be expressed according to the $\mathrm{CI}_{\mathrm{NE}}$ of forage $\left(\mathbf{C I}_{\mathbf{f}} ; \mathrm{min} /\right.$ $\mathrm{MJ}$ of NE) and concentrate $\left(\mathbf{C I}_{\mathbf{c}} ; \min / \mathrm{MJ}\right.$ of NE):

$$
\mathrm{CI}_{\mathrm{NE}}=\left(\frac{\mathrm{NEI}_{\mathrm{c}} \times \mathrm{CI}_{\mathrm{c}}+\mathrm{NEI}_{\mathrm{f}} \times \mathrm{CI}_{\mathrm{f}}}{\mathrm{NEI}_{\mathrm{c}}+\mathrm{NEI}_{\mathrm{f}}}\right) .
$$

Substituting equations 10 and 11 into equation 5 makes it possible to express $\mathrm{NEI}_{\mathrm{f}}$ as a function of $\mathrm{NEI}_{0}, \mathrm{CT}_{\max }$, $\mathrm{NEI}_{c}, \mathrm{CI}_{c}$, and $\mathrm{CI}_{\mathrm{f}}$ :

$$
\begin{aligned}
& \mathrm{NE}_{\mathrm{f}}=-\left[\mathrm{NEI}_{\mathrm{c}}+\frac{\left(\mathrm{NEI}_{0}\right)^{2} \times \mathrm{CI}_{\mathrm{f}}}{2 \times 4 \times \mathrm{CT}_{\max }}-\frac{\mathrm{NEI}_{0}}{2}\right]+
\end{aligned}
$$

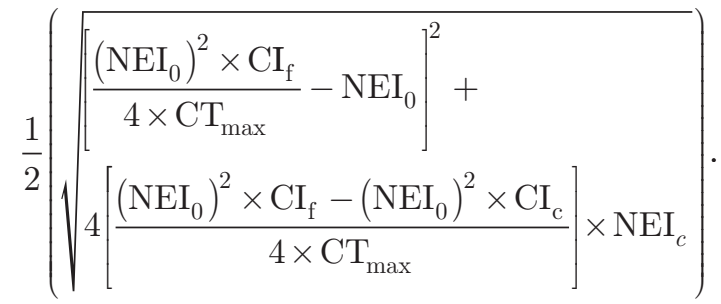

Only the positive solution is shown, as the negative solution implies decreasing $\mathrm{NEI}_{\mathrm{f}}$ intake at increasing $\mathrm{CI}_{\mathrm{f}}$ for NEI higher than $1 / 2 \mathrm{NEI}_{0}$. The differentiation of equation 12 results in the forage-to-concentrate substitution rate $\left(\mathrm{dNEI}_{\mathrm{f}} / \mathrm{dNEI}_{\mathrm{c}}\right)$ expressed in equation 13

$$
\begin{aligned}
& \frac{\mathrm{dNEI}_{\mathrm{f}}}{\mathrm{dNEI}_{\mathrm{c}}}=-1+ \\
& \frac{1}{4}\left[\frac{\mathrm{CI}_{\mathrm{f}}-\mathrm{CI}_{\mathrm{c}}}{\sqrt{\left(\frac{\mathrm{CI}_{\mathrm{f}}}{4}-\frac{\mathrm{CT}_{\text {max }}}{\mathrm{NEI}_{0}}\right)^{2}+\left(\frac{\mathrm{CI}_{\mathrm{f}}-\mathrm{CI}_{\mathrm{c}}}{\mathrm{NEI}_{0}^{2}}\right) \times \mathrm{CT}_{\text {max }} \times \mathrm{NEI}_{\mathrm{c}}}} .\right.
\end{aligned}
$$

Equation 13 describes the change in $\mathrm{NE}_{\mathrm{f}}$ with changing $\mathrm{NEI}_{c}$, as a function of $\mathrm{CI}_{\mathrm{f}}, \mathrm{CI}_{\mathrm{c}}, \mathrm{CT}_{\max }$, and $\mathrm{NEI}_{0}$.

\section{Model Evaluation Data}

Evaluation of the NEI model was conducted on independent data from 19 indoor experiments with a total of 80 treatment means in lactating dairy cows of varying breeds and parities. The 80 treatment means were compiled from 812 cows and the mean BW of the treatment groups ranged from 416 to $659 \mathrm{~kg}$. The included experiments were retrieved from a Scandinavian database and used both Latin square and continuous designs and were chosen because their feeding, housing, and management 
Table 3. Dry matter intake, net energy intake (NEI), DIM, and ECM yield of 80 treatment means (19 experiments) expressed as mean, SD, minimum, and maximum values

\begin{tabular}{lcccc}
\hline Item & Mean & SD & Minimum & Maximum \\
\hline DMI (kg of DM/d) & 21.8 & 3.12 & 15.0 & 28.7 \\
NEI (MJ of NE/d) & 138 & 19.0 & 87.8 & 168 \\
DIM & 133 & 46.9 & 28.0 & 214 \\
ECM (kg/d) & 31.6 & 5.65 & 18.7 & 41.1 \\
\hline
\end{tabular}

were similar to those in the data used for modeling. Data included in this evaluation have previously been published and were all conducted in Denmark, Sweden, Poland, or the United States (Casper and Schingoethe, 1988; Piepenbrink et al., 1996; Armentano et al., 1997; Bremmer et al., 1997; Overton et al., 1998; Xu et al., 1998; Bateman et al., 1999; Pisulewski and Kowalski, 1999; Soder and Holden, 1999; Ingvartsen et al., 2001; Samuelson et al., 2001; Mogensen and Kristensen, 2002; Leonardi et al., 2003; Eriksson et al., 2004; Mogensen et al., 2008; Weisbjerg et al., 2008; Ordway et al., 2009; Wallsten and Martinsson, 2009; Alstrup et al., 2016). The mean, minimum, and maximum values of DMI, DIM, NEI, and ECM are presented in Table 3.

The 19 experiments included groups of cows from 6 breeds with 8 treatment means distributed among Swedish Red, 4 treatment means among Brown Swiss, 2 treatment means among Jersey, 1 treatment mean from Danish Red, 5 treatment means among Polish red or white, and 60 treatment means among Holstein. The 19 experiments were conducted between 1988 and 2011 and included 13 grass and grass-clover silages, 6 alfalfa silages, 9 maize silages, 5 barley or barley-pea wholecrop silages, 10 alfalfa hays, 1 grass hay, and 1 barley straw, fed either as TMR (69 treatment means) or with separate concentrate allocation (11 treatment means). Table 4 presents mean, minimum, and maximum values of nutrient composition of the total diets and of the forages used in the experiments, divided into rations fed as TMR and forage fed ad libitum supplemented with concentrate.

\section{Evaluation and Statistical Analyses of the NEI Model}

The prediction accuracy of the NEI model was evaluated by mean square prediction error (MSPE; equation 14):

$$
\operatorname{MSPE}=\sum_{i=1}^{n}\left(A_{i}-P_{i}\right)^{2} / n
$$

where $A_{i}$ is the observed NEI for group $i, P_{i}$ is the predicted NEI for group $i$, and $n$ is the number of pairs of $A$ and $P$ being compared (Bibby and Toutenberg, 1977).

The MSPE quantifies the prediction across experiments and it can be considered the sum of error due to central tendency (ECT), error due to regression (ER), and error due to disturbance (ED), as described by Bibby and Toutenberg (1977). This decomposition of the MSPE can be recovered from a simple linear regression of the difference between $A$ and $P$ on the difference between $P$ and its mean.

To decompose the error due to disturbance into variation between and within experiments, the simple linear regression may be extended by a random effect of experiment. Thus, the simple linear regression (equation 15) was fitted both with and without the random effect $\mathrm{E}(E x p)$, and the associated decomposition of MSPE (equation 16) was found as the decrease in MSPE when terms were included from left to right (equation 15):

$$
\begin{gathered}
A_{i}-P_{i}=\alpha+\mathrm{E}\left(\operatorname{Exp}_{i}\right)+\beta \\
\quad \times\left[P_{i}-\operatorname{mean}(P)\right]+\varepsilon_{i},
\end{gathered}
$$

\begin{tabular}{|c|c|c|c|c|c|c|c|c|}
\hline \multirow[b]{2}{*}{ Item } & \multicolumn{4}{|c|}{ TMR } & \multicolumn{4}{|c|}{ Separate feeding } \\
\hline & Mean & $\mathrm{SD}$ & Minimum & Maximum & Mean & $\mathrm{SD}$ & Minimum & Maximum \\
\hline $\begin{array}{l}\mathrm{OMD}^{1}(\%) \\
\mathrm{CP}^{2}(\mathrm{~g} / \mathrm{kg} \text { of } \mathrm{DM}) \\
\mathrm{NDF}_{\mathrm{t}}^{3}(\mathrm{~g} / \mathrm{kg} \text { of } \mathrm{DM}) \\
\mathrm{NDF}_{\mathrm{f}}^{4}(\mathrm{~g} / \mathrm{kg} \text { of } \mathrm{DM}) \\
\mathrm{iNDF}_{\mathrm{t}}(\mathrm{g} / \mathrm{kg} \text { of } \mathrm{DM}) \\
\mathrm{CI}_{\mathrm{DM}^{6}}{ }^{6}(\mathrm{~min} / \mathrm{kg} \text { of } \mathrm{DM})\end{array}$ & $\begin{array}{l}72.9 \\
176 \\
309 \\
389 \\
117 \\
35.1\end{array}$ & $\begin{array}{c}3.30 \\
16.4 \\
49.5 \\
38.2 \\
46.7 \\
9.27\end{array}$ & $\begin{array}{l}67.1 \\
148 \\
219 \\
322 \\
31.7 \\
24.6\end{array}$ & $\begin{array}{l}79.0 \\
231 \\
409 \\
479 \\
197 \\
62.5\end{array}$ & $\begin{array}{c}75.4 \\
177.3 \\
342 \\
441 \\
86.2 \\
38.2\end{array}$ & $\begin{array}{c}1.59 \\
17.0 \\
18.4 \\
17.0 \\
32.9 \\
8.11\end{array}$ & $\begin{array}{c}73.1 \\
163 \\
309 \\
417 \\
60.5 \\
30.2\end{array}$ & $\begin{array}{c}77.4 \\
212 \\
371 \\
468 \\
137 \\
49.4\end{array}$ \\
\hline $\begin{array}{l}{ }^{1} \text { Organic matter digestil } \\
{ }^{2} \text { Crude protein concentr } \\
{ }^{3} \text { Neutral detergent fiber } \\
{ }^{4} \text { Neutral detergent fiber } \\
{ }_{5}^{5} \text { Indigestible NDF conce }\end{array}$ & $\begin{array}{l}\text { lity of } t \\
\text { tion of } \\
\text { concentr } \\
\text { concentr } \\
\text { tration }\end{array}$ & $\begin{array}{l}\text { tal diet } \\
\text { otal die } \\
\text { ation of } \\
\text { ation of } \\
\text { of diet I }\end{array}$ & $\begin{array}{l}\text { DM. } \\
\text { total diet D } \\
\text { forage DM. } \\
\text { M. }\end{array}$ & & & & & \\
\hline
\end{tabular}

Table 4. Nutritional characteristics of the 80 diets from 19 experiments expressed as mean, SD, minimum, and maximum values 
and

$$
\mathrm{MSPE}=\mathrm{ECT}+\mathrm{ECT}_{E x p}+\mathrm{ER}+\mathrm{ED},
$$

where $A_{i}$ is observed NEI for group $i, P_{i}$ is predicted NEI for group $i, \alpha$ is the regression intercept expressed as the fixed part, $\mathrm{E}\left(E_{\left.x p_{i}\right)}\right)$ is the random intercept due to experiment $i, \beta$ is the regression slope, and $\varepsilon_{i}$ is the error. In the random effect model (equation 16), ED quantifies the prediction error within experiments, which is relevant, for example, when comparing different diets within an experiment.

Root mean square prediction error (RMSPE) is expressed as percentage of the observed NEI by dividing the RMSPE (MJ of NE/d) by the mean observed NEI (MJ of NE/d) multiplied by $100 \%$.

Relationships between residual NEI (observed minus predicted) and daily ECM yield $(\mathrm{kg} / \mathrm{d}), \mathrm{BW}(\mathrm{kg})$ of the animals, the proportion of first-lactation cows in the treatment group, the dietary concentration of the $\mathrm{NDF}_{\mathrm{f}}$, the $\mathrm{CI}_{\mathrm{NE}}$ of the diets, and the $\mathrm{CP}(\mathrm{g} / \mathrm{kg}$ of DM) were analyzed using linear mixed modeling with random effect of experiment.

\section{RESULTS AND DISCUSSION}

\section{Linear Relationship Between $\mathrm{NEI}$ and $\mathrm{CI}_{N E}$}

The NEI by lactating dairy cows decreased linearly with increasing $\mathrm{CI}_{\mathrm{NE}}$ values of TMR diets within the different experiments (Table 5). The validation plots of the statistical model [7] showed agreement with the stated linearity between $\mathrm{NEI}$ and $\mathrm{CI}_{\mathrm{NE}}$ (equation 4; Figure 1). The estimated intercept values from the individual experiments are considered to represent the metabolic net energy intake capacity $\left(\mathrm{NEI}_{0}^{\mathrm{fixed}}\right)$ in a theoretical condition, when the intake of these populations of cows only is constrained by the metabolic capacity to metabolize absorbed nutrients for maintenance, milk, and body stores. The $\mathrm{NEI}_{0}^{\text {fixed }}$ and slope $\left(b^{\text {fixed }}\right)$ of the average population are presented in Table 5 .

Table 5. Fixed effect estimates from the net energy intake (NEI) model as a function of chewing index $\left(\mathrm{CI}_{\mathrm{NE}}\right)$ based on 136 treatment means from 14 experiments

\begin{tabular}{lccc}
\hline & & \multicolumn{2}{c}{$95 \%$ confidence interval } \\
\cline { 3 - 4 } Item $^{1}$ & Estimate & Minimum & Maximum \\
\hline $\mathrm{NEI}_{0}^{\text {fixed }}(\mathrm{MJ}$ of NE/d) & 184 & 163 & 204 \\
$b^{\text {fixed }}\left[(\mathrm{MJ} \text { of NE} / \mathrm{d})^{2} /(\mathrm{min} / \mathrm{d})\right]$ & -10.0 & -12.7 & -7.33 \\
\hline${ }^{1} \mathrm{NEI}_{0}^{\text {fixed }}=$ metabolic net energy intake capacity of the cows; $b^{\text {fixed }}=$ \\
decrease in net energy intake with increasing chewing index of the diet.
\end{tabular}

Variations among experiments in their $\mathrm{NEI}_{0}$ and slope values were estimated as var $\left[\mathrm{NEI}_{0}^{\operatorname{Exp}}\left(\operatorname{Exp}_{i}\right)\right]=910.5$, $\operatorname{var}\left[b^{\operatorname{Exp}} \quad\left(\operatorname{Exp}_{i}\right)\right] \quad=13.2, \quad$ and $\operatorname{cov}\left[\operatorname{NEI}_{0}^{\operatorname{Exp}}\left(\operatorname{Exp}_{i}\right), b^{\operatorname{Exp}}\left(\operatorname{Exp}_{i}\right)\right]=-104.3$. Variations between treatment means within experiments were estimated as $\operatorname{var}\left(\mathrm{NEI}_{0, i}^{T M}\right)=569, \quad \operatorname{var}\left(b_{i}^{T M}\right)=9.97, \quad$ and $\operatorname{cov}\left(\operatorname{NEI}_{0, i}^{T M}, b_{i}^{T M}\right)=-73.9$.

Each of the 14 experiments had their own intercept and slope, implying that the groups of cows within experiments were more similar than groups of cows across experiments. Different predicted $\mathrm{NEI}_{0}$ across experiments could indicate different production potentials between groups of cows.

The difference between experiments was tested by removing the random intercept and slope within the experiment from equation 7, whereby the AIC value for the model fit increases by 98.9 . As a change larger than 10 indicates a much worse fit, this shows the difference between experiments.

\section{Cl}

The $\mathrm{CI}_{\mathrm{NE}}$ values of the diets were estimated based on NorFor principles, with concentrates given a fixed value of $4 \mathrm{~min} / \mathrm{kg}$ of DM and forage ranged from 40 to 130 $\mathrm{min} / \mathrm{kg}$ of DM depending on concentrations of NDF and indigestible NDF and particle length (NorFor, 2010; Nørgaard et al., 2011). The $\mathrm{CI}_{\mathrm{f}}$ values used in the 136 treatments ranged from 42 to $126 \mathrm{~min} / \mathrm{kg}$ of $\mathrm{DM}$, demonstrating a wide variation of forage characteristics in the different dietary treatments. The NorFor recommends a minimum dietary $\mathrm{CI}_{\mathrm{NE}}$ value for a mixed diet of $30 \mathrm{~min} / \mathrm{kg}$ of $\mathrm{DM}$, which corresponds to about 3.8 min/MJ of NE to prevent rumen disorders, which often have been associated with excessive amounts of concentrates (Nørgaard et al. 2011). The increase in NEI with decreasing dietary $\mathrm{CI}_{\mathrm{NE}}$ (Figure 1) is in line with the negative relationship between the dietary concentration of NDF and DMI in dairy cows demonstrated by Mertens (1994) and Allen (2000).

The $\mathrm{CI}_{\mathrm{NE}}$ value generally decreases at increasing proportion of concentrates and at increasing digestibility of forage, reduced particle length, and lower NDF content of forages. This is in agreement with Allen (2000), who observed increased forage intake due to lower NDF content, chopping, and higher digestibility of forage, which decreases the $\mathrm{CI}_{\mathrm{f}}$ and $\mathrm{CI}_{\mathrm{NE}}$ values. The negative effects of decreased silage DM concentration and increased concentrations of silage fermentation products, which are addressed and incorporated into the total DM index model by Huhtanen et al. (2007), are not addressed in the present model. 


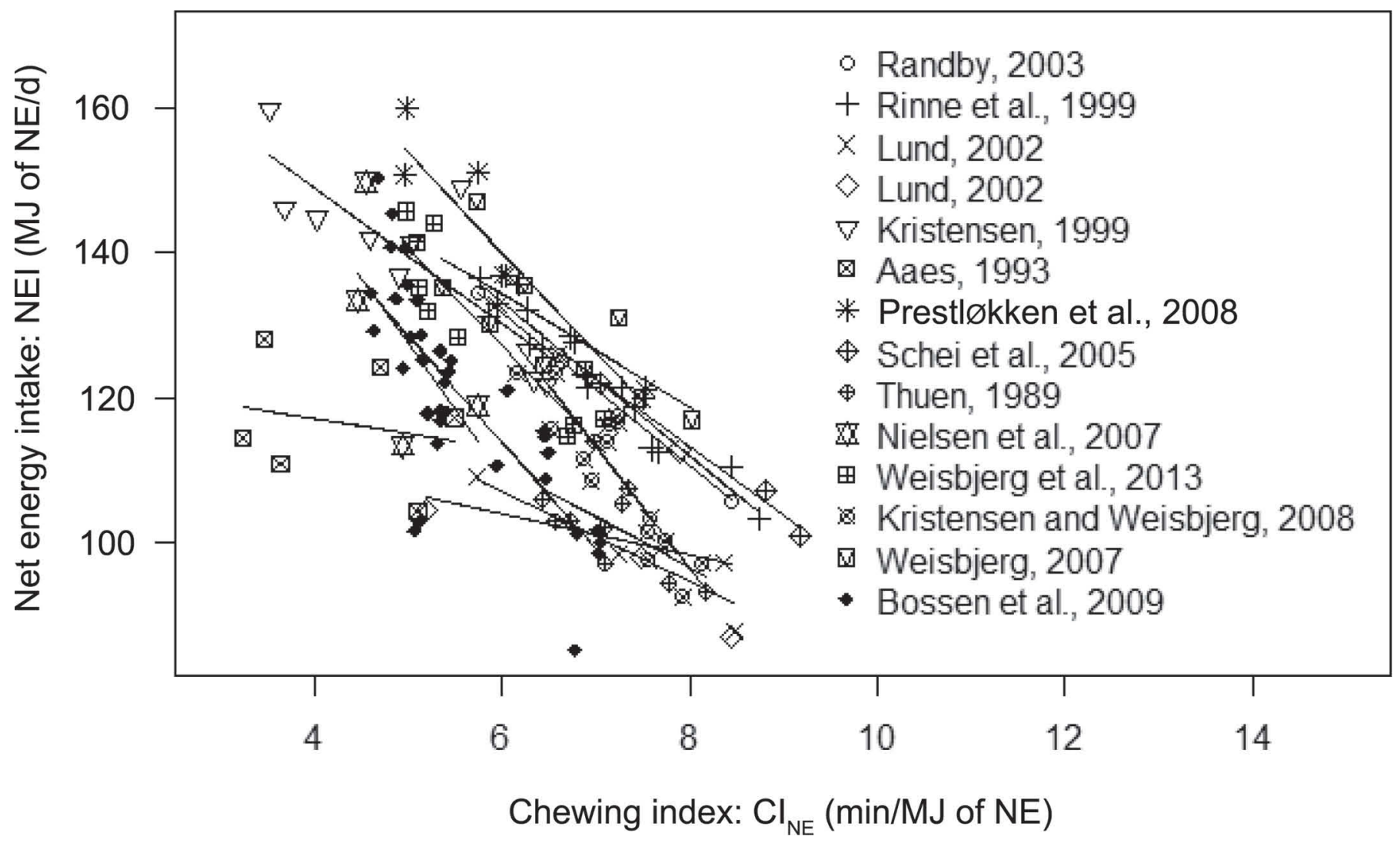

Figure 1. Net energy intake (NEI) of lactating dairy cows expressed as a function of corrected chewing index $\left(\mathrm{CI}_{\mathrm{NE}}\right)$, with treatment means from 14 individual experiments.

Evaluation of the NEI model is less vulnerable to between-cow variations due to the use of mean treatment NEI values. Huhtanen et al. (2011) found larger residual DMI values when the models were evaluated on individual cow data instead of mean treatment data, and differences between prediction of individual intake and mean treatment intake could be due to lack of important animal characteristics in the model, such as milk yield and BW.

\section{Relationship Between Slope $b$ and Intercept NEI}

Figure 2 shows a scatterplot of the 136 predicted slopes $b^{\text {fixed }}+b^{\operatorname{Exp}}\left(\operatorname{Exp}_{i}\right)+b_{i}^{T M}$ and intercepts $\mathrm{NEI}_{0}^{\text {fixed }}+\mathrm{NEI}_{0}^{E x p}\left(\operatorname{Exp}_{i}\right)+\mathrm{NEI}_{0, i}^{T M}$ together with the estimated power relation given in equation 8

$$
\left\{\begin{array}{l}
b^{\text {fixed }}+b^{\operatorname{Exp}}\left(\operatorname{Exp}_{i}\right)+b_{i}^{T M}= \\
k \times\left[\mathrm{NEI}_{0}^{\text {fixed }}+\mathrm{NEI}_{0}^{\operatorname{Exp}}\left(\operatorname{Exp}_{i}\right)+\mathrm{NEI}_{0, i}^{T M}\right]^{a}
\end{array}\right\} .
$$

The correlation between the predictions is evident, and this is also shown in the normal quantile and residual plots. As the nonlinear regression stated in equation 8 assumes observations to be independent, the estimates, and in particular the confidence intervals, should be used with care. The estimates and the $95 \%$ confidence intervals are given in Table 6 for $k$ and $a$. This shows agreement with $a=2$, and hence confirms the simple linear relationship that Nørgaard and Mølbak (2001) found between the estimated slope and the squared intercept values from different types of cattle without correction of the $\mathrm{CI}_{\mathrm{DM}}$ values for intake of $\mathrm{NDF}_{\mathrm{f}}$. The demonstration of $a=2$ is a bearing point of the NEI model, as $a$ different from 2 would imply that $\mathrm{CT}_{\max }$ will be dependent on the $\mathrm{NEI}_{0}$ value. The estimate and the $95 \%$ confidence interval for $\mathrm{CT}_{\max }=1 /(4 \times k)$ are also shown in Table 6 , where the exponent is fixed at 2 .

A line in Figure 2 was fitted to describe the relationship between the estimated slopes $\left[b^{\text {fixed }}+b^{\operatorname{Exp}}\left(\operatorname{Exp}_{i}\right)+b_{i}^{T M}\right]$ and the intercepts $\left.\mathrm{NEI}_{0}^{\text {fixed }}+\mathrm{NEI}_{0}^{E x p}\left(\operatorname{Exp}_{i}\right)+\mathrm{NEI}_{0, i}^{T M}\right]$, where $i$ are treatment means from 1 to 136 and $\operatorname{Exp}_{i}$ are experiments 1 to 14 , both with $a$ as free and fixed to 2 (Figure 2). The line of $a$ as free and $a$ as fixed to 2 were nearly identical making a difference impossible to visualize, resulting in 

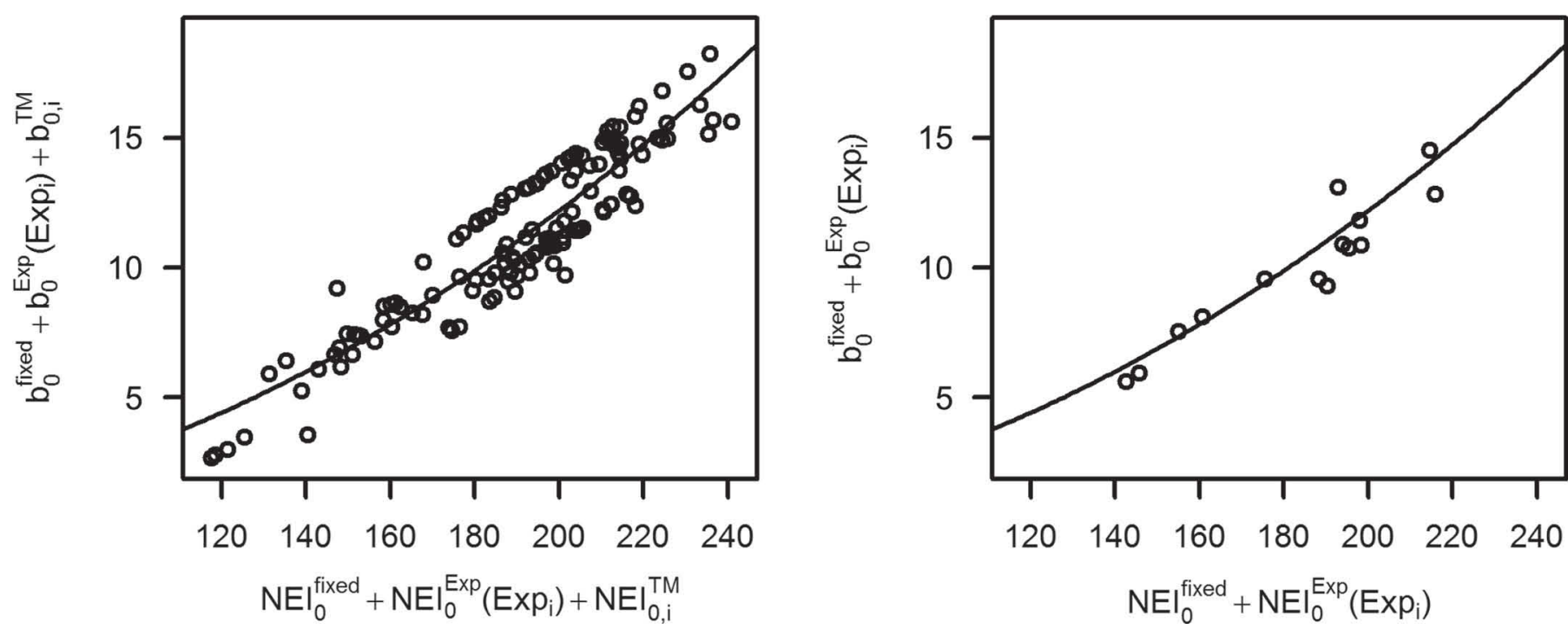

Figure 2. The relationship between estimated slope $b^{\text {fixed }}+b^{E x p}\left(\operatorname{Exp}_{i}\right)+b_{i}^{T M}$ and intercept $\mathrm{NEI}_{0}^{\mathrm{fixed}}+\mathrm{NEI}_{0}^{\operatorname{Exp}}\left(\operatorname{Exp}_{i}\right)+\mathrm{NEI}_{0, i}^{T M}$ values of the 136 treatment means $(T M)$ from 14 experiments. The line demonstrates $a$ as fixed to 2 (left). The relationship between estimated slope $b^{\text {fixed }}+$ $b^{E x p}\left(\operatorname{Exp}_{i}\right)$ and intercept $\mathrm{NEI}_{0}^{\text {fixed }}+\mathrm{NEI}_{0}^{E x p}\left(\operatorname{Exp}_{i}\right)$ values from the 14 experiments is plotted and a line demonstrating $a$ as fixed to 2 is visualized (right). NEI $=$ net energy intake; $a=$ exponent; $b=$ slope; $\operatorname{Exp}_{i}=$ the experiment of the $i$ th observation.

presentation of the fitted line when the exponent $a$ is fixed at 2 .

\section{Maximum Chewing Time}

The slope values were clearly proportional with the squared intercept values and with a proportionality factor $k$ (equation 6 ), and consequently substantiate the intake model (equation 5). This result in a constant $\mathrm{CT}_{\max }$ of $819 \mathrm{~min} / \mathrm{d}$ with a range of 805 to $835 \mathrm{~min} / \mathrm{d}$, which is lower compared with the maximum $\mathrm{CT}$ value of $1,000 \mathrm{~min} / \mathrm{d}$ reported in the review by Nørgaard (1989). However, most of the reported values for daily

Table 6. Fixed effect estimates of $k$, exponent $a$, and $\mathrm{CT}_{\max }$

\begin{tabular}{lccc}
\hline & & \multicolumn{2}{c}{$95 \%$ confidence interval } \\
\cline { 3 - 4 } Item & Estimate & Minimum & Maximum \\
\hline$k^{1}\left(10^{-3}\right)$ & 0.305 & 0.299 & 0.311 \\
$a^{2}$ & 1.99 & 1.83 & 2.16 \\
$\mathrm{CT}_{\max }{ }^{3}$ & 819 & 805 & 835 \\
\hline
\end{tabular}

${ }^{1}$ The proportionality factor, $k$, which describes the relation between the slope $b^{\text {fixed }}+b^{E x p}\left(E x p_{i}\right)+b_{i}^{T M}$ and the intercept expressing the metabolic net energy intake (NEI) capacity $\mathrm{NEI}_{0}^{\text {fixed }}+\mathrm{NEI}_{0}^{E x p}\left(\operatorname{Exp}_{i}\right)+\mathrm{NEI}_{0}^{T M} \cdot b=$ slope $; \operatorname{Exp}_{i}=$ the experiment of the $i$ th observation; $T M=$ treatment mean.

${ }^{2}$ The exponent, $a$, defines the relation between the slope $b$ and the intercept $N E I_{0}$, and if 2 , it results in a constant chewing time maximum $\left(\mathrm{CT}_{\max }\right)$.

${ }^{3}$ The constant maximum chewing time expressed as minutes per day, assuming $a=2$. time spent chewing in ad libitum-fed cattle ranged between 500 and $800 \mathrm{~min} / \mathrm{d}$ (Nørgaard, 1989).

\section{Estimates of Animal Characteristics Used for Prediction of $\mathrm{NEI}_{0}$}

The variable estimates retrieved from the function describing $\mathrm{NEI}_{0}$ based on significant and biologically important animal characteristics are presented in Table 7. The final variables left after model reduction and with significant $P$ values were DIM, (DIM) $)^{2}$, and ECM. The observed NEI were not significantly related to the proportion of primiparous cows or $\mathrm{BW}^{0.75}$. The $\mathrm{BW}^{0.75}$ is the driver for the energy requirement for maintenance and it was retained in the model to be able to separate the effects of breed size and lactation number from milk yield in prediction of the most likely $\mathrm{NEI}_{0}$ value for a specific group of cows. The estimates of the included animal characteristics were used in prediction of NEI by the expanded NEI model (equation 9).

Intercept. The $\mathrm{NEI}_{0}$ value of each treatment group of cows was predicted from a linear model including intercept, ECM, DIM, (DIM) $)^{2}$, and $\mathrm{BW}^{0.75}$. The intercept of the $\mathrm{NEI}_{0}$ model was nonsignificant but maintained due to the biological interpretation of the negative value, considered to reflect the general negative energy balance often at the beginning of lactation, when the DIM value approaches zero.

$\boldsymbol{B} \boldsymbol{W}$. Body weight was used in the NEI model in the correction of the dietary $\mathrm{CI}_{\mathrm{NE}}$ value, as large cows spend less time chewing $1 \mathrm{~kg}$ of forage NDF compared with 
Table 7. Variable estimates of the animal characteristics used for prediction of the metabolic net energy intake capacity $\left(\mathrm{NEI}_{0}\right)$, DIM, ECM yield, and metabolic body weight $\left(\mathrm{BW}^{0.75}\right)^{1}$

\begin{tabular}{|c|c|c|c|c|c|}
\hline \multirow[b]{2}{*}{ Variable } & \multirow[b]{2}{*}{ Units } & \multirow[b]{2}{*}{ Estimate } & \multirow[b]{2}{*}{$\mathrm{SE}$} & \multicolumn{2}{|c|}{$95 \%$ confidence interval } \\
\hline & & & & Minimum & Maximum \\
\hline $\begin{array}{l}\mathrm{a}_{0}{ }^{2} \\
\mathrm{a}_{1}{ }^{3} \\
\mathrm{a}_{2}{ }^{4} \\
\mathrm{a}_{3}{ }^{5} \\
\mathrm{a}_{4}{ }_{4}\end{array}$ & $\begin{array}{l}\text { MJ of } \mathrm{NE} \\
\text { MJ of } \mathrm{NE} / \mathrm{d} \\
\text { MJ of } \mathrm{NE} / \mathrm{d}^{2} \\
\text { MJ of } \mathrm{NE} / \mathrm{kg}^{0} \\
\text { MJ of } \mathrm{NE} / \mathrm{kg}^{0.75}\end{array}$ & $\begin{array}{l}-46.1 \\
\quad 0.73^{* * *} \\
-0.002^{* * *} \\
4.67^{* * *} \\
0.39\end{array}$ & $\begin{array}{l}34.4 \\
0.14 \\
4.5 \times 10^{-4} \\
0.63 \\
0.29\end{array}$ & $\begin{array}{c}-111 \\
0.46 \\
-0.003 \\
3.47 \\
-0.23\end{array}$ & $\begin{array}{c}23.8 \\
1.01 \\
-0.001 \\
5.94 \\
0.94\end{array}$ \\
\hline $\begin{array}{l}{ }^{1} \mathrm{NEI}_{0}=\mathrm{o} \\
{ }^{2} \text { Intercept } \\
{ }^{3} \text { Regressic } \\
{ }^{4} \text { Regressic } \\
{ }^{5} \text { Regressic } \\
{ }^{6} \text { Regressic } \\
{ }^{* * *} P<0\end{array}$ & $\begin{array}{l}\times \text { DIM }+\mathrm{a}_{2} \times(\mathrm{I} \\
\text { function describil } \\
\text { ficient for effect of } \\
\text { ficient for effect of } \\
\text { ficient for effect of } \\
\text { ficient for effect of }\end{array}$ & $\begin{array}{l}\mathrm{a}_{3} \times \mathrm{ECM}+ \\
\text { olic } \mathrm{NEI}_{0} \text {. } \\
\text { lared. } \\
\text { eld. }\end{array}$ & $\mathrm{BW}^{0.75}$. & & \\
\hline
\end{tabular}

small cows (e.g., Jersey cows; Nørgaard et al., 2011). The correlation between BW and capacity of the digestive tract was taken in to consideration by correcting the $\mathrm{CI}_{\mathrm{NE}}$ values for $\mathrm{BW}$ different from the standard of $625 \mathrm{~kg}$ used in the NorFor digestive system (Nørgaard et al., 2011). As described by Mertens (1994) physical capacity for intake of $\mathrm{NDF}_{\mathrm{f}}$ is proportional to $\mathrm{BW}$. The estimated $\mathrm{NEI}_{0}$ of $0.39 \mathrm{MJ}$ of $\mathrm{NE} / \mathrm{kg}$ of $\mathrm{BW}^{0.75}$ is numerically larger than required for maintenance according to NRC (2001; 0.33 MJ of $\mathrm{NE} / \mathrm{kg}$ of $\mathrm{BW}^{0.75}$ ) and NorFor (Nielsen and Volden, 2011; 0.31 MJ of NE/ $\mathrm{kg}$ of $\left.\mathrm{BW}^{0.75}\right)$. The numeric higher estimate of 0.39 per $\mathrm{kg}$ of $\mathrm{BW}^{0.75}$ might be related to the fact that the size of the animal affects the capacity to deposit body stores. The use of BW in the prediction models was, however, questioned by Zom et al. (2012). The negative estimated intercept value might reflect the typical negative energy balance in early lactation (Løvendahl et al., 2010) when the DIM value approaches zero.

Milk Yield. The $\mathrm{NEI}_{0}$ value was estimated to increase by $4.7 \mathrm{MJ}$ of $\mathrm{NE} / \mathrm{kg}$ of ECM even though the energy requirement is $3.14 \mathrm{MJ}$ of NE/ $\mathrm{kg}$ of ECM (Sjaunja et al., 1990). The higher marginal increase in $\mathrm{NEI}_{0}$ per kilogram of ECM compared with requirement might be related to the use of observed ECM and not the potential ECM yield. In a meta-analysis, Jensen et al. (2015b) observed a diminishing nonlinear response of ECM to increasing NEI estimated by NorFor, similar to the present study. One kilogram of potential increase in ECM yield results in an increased NEI of $3 \mathrm{MJ}$ of $\mathrm{NE}$ (using the NEI model; equation 1), an $\mathrm{NEI}_{0}$ value of $200 \mathrm{MJ}$ of $\mathrm{NE} / \mathrm{d}$, a $\mathrm{CI}_{\mathrm{NE}}$ value of $3 \mathrm{~min} / \mathrm{MJ}$ of $\mathrm{NE}$, and a marginal effect of increased milk yield potential on the $\mathrm{NEI}_{0}$ value of $4.7 \mathrm{MJ}$ of $\mathrm{NE} / \mathrm{kg}$, which is similar to the NE requirement (3.14 MJ) per kilogram of ECM. The use of observed ECM in prediction models has been questioned (Huhtanen et al., 2011; Zom et al., 2012) because milk yield, similar to BW, is an output variable highly dependent on the feed input (Zom et al., 2012). Friggens et al. (1998) demonstrated that observed milk yield is related to the current diet and therefore is not useful in predicting intake capacity in relation to diets other than those consumed at the point of milk observations. However, observed milk yield can be used to predict intake capacity if the aim is to sustain or adjust a given level of milk production in specific dairy herd (Keady et al., 2004). Observed milk yield variables have been included in prediction models in several different variations (Vadiveloo and Holmes, 1979; ARC, 1980; Mertens, 1987; Kertz et al., 1991; NRC, 2001; Thomas, 2004; Faverdin et al., 2011). Huhtanen et al. (2011) discussed that observed milk yield is not a preferred variable for prediction equations, but recognized the importance of a variable that introduces milk production capacity into prediction models. Therefore, Huhtanen et al. (2011) emphasized the usefulness of variables that can describe the requirements for energy to milk production and used a standardized ECM variable. In the present evaluation, the NEI model shows no relation between ECM and the residual NEI.

DIM. The $\mathrm{NEI}_{0}$ of the NEI model was estimated as a second-degree polynomial of DIM [f(DIM)], which leads to symmetric decreases in the prediction of $\mathrm{NEI}_{0}$ value for higher or lower DIM values than the relative late peak value of DIM $=188$ for $\mathrm{f}(\mathrm{DIM})$. This may lead to a systematic overprediction of the $\mathrm{NEI}_{0}$ in early lactation (DIM <25) and an underprediction of $\mathrm{NEI}_{0}$ in late lactation (DIM >275), which are both outside the present DIM range of the data set. Both NorFor (Volden et al., 2011) and NRC (2001) have used a polynomial effect of exponential functions of DIM, which enables a steep increase in early lactation and 
Table 8. Accuracy of a model predicting net energy intake (NEI) in dairy cows analyzed across 19 experiments; results are based on 80 treatment means $(\mathrm{N})$

\begin{tabular}{|c|c|c|c|c|}
\hline \multirow[b]{2}{*}{ Model } & \multicolumn{2}{|c|}{$\begin{array}{c}\text { Mean NEI } \\
\text { (MJ of NE/d) }\end{array}$} & \multirow[b]{2}{*}{$\mathrm{N}$} & \multirow{2}{*}{$\begin{array}{c}\mathrm{RMSPE}^{1} \\
(\mathrm{MJ} \text { of NE/d }\end{array}$} \\
\hline & Predicted & Observed & & \\
\hline NEI & 136 & 138 & 80 & 11.1 \\
\hline
\end{tabular}

${ }^{1} \mathrm{RMSPE}=$ square root of mean square prediction error in MJ of NE/d (Bibby and Toutenberg, 1977).

a relative flat decrease in intake capacity during late lactation. The combination of the negative intercept value of 46.1, f(DIM), and the high effect of ECM of 4.7 versus $3.14 \mathrm{MJ}$ of $\mathrm{NE} / \mathrm{kg}$ of ECM leads to an underestimation of $\mathrm{NEI}_{0}$ for low-yielding cows in late lactation and especially for dry cows. This quadratic effect of DIM is similar to that used in NRC (2001), TDMI (Huhtanen et al., 2011), Gruber et al. (2004), NorFor (Volden et al., 2011), and GrazeIn (Faverdin et al., 2011) models predicting DMI to be curve linearly related to DIM. This quadratic use of DIM is related to the drop in energy requirements for milk yield after peak yield and relates the interaction between peak lactation and energy balance, which is around zero at 20 to 30 DIM and around maximum DMI from 60 to 90 DIM (Bossen and Weisbjerg, 2009; Bossen et al., 2009). Standard lactation curves related to lactation number could possibly be used instead of the DIM variables for representing energy requirement for lactation; however, the effect of the different abilities for deposition of energy in body stores throughout the whole lactation on the $\mathrm{NEI}_{0}$ value would be missing.

\section{Accuracy of Predicted NEI Evaluated Across Experiments}

Results of the evaluation of the NEI model across the 19 experiments are presented as means, with statistical criteria and regression estimates, in Tables 8 and 9. The model predicts NEI with an RMSPE of approximately $11 \mathrm{MJ}$ of NE/d, resulting in $8.0 \%$ of observed NEI. This is below the $10 \%$ criterion for satisfactory prediction of feed intake described by Fuentes-Pila et al. (1996), demonstrating an accurate model.

The decomposed MSPE in Table 9 describes the differences in location of the errors, and thereby the strengths and weaknesses of the model. Table 9 shows the decomposition of the MSPE into ECT, ER, and ED of the model evaluated across the 19 experiments. The error located in ED, expressed as percentage of MSPE, was $84.9 \%$, the error located in ER, expressed as percentage of MSPE was $10.9 \%$, and the error due to ECT, expressed as percentage of MSPE, was $4.2 \%$ for the NEI model.

Figure 3 presents the centralized residual plots, showing residuals (observed minus predicted) plotted on the $\mathrm{y}$-axis and the centralized predicted NEI on the x-axis. The centralized residual plot and the slope coefficients (Table 9) show that the NEI model significantly underpredict low intakes and overpredict medium to high intakes, demonstrating largest effect of feeding level on prediction of NEI. In general, the NEI model tended to $(P=0.054)$ underpredict NEI, as demonstrated by the positive intercept values (Table 9 ). The regression values in Table 9 are associated with the black regression line in Figure 3.

Table 9. Decomposed evaluation criteria, regression estimates, and significance level of the model predicting net energy intake (NEI) in dairy cows, evaluated across and within 19 experiments

\begin{tabular}{|c|c|c|c|c|c|c|c|c|}
\hline \multirow[b]{2}{*}{ Model } & \multirow[b]{2}{*}{$\mathrm{N}$} & \multicolumn{5}{|c|}{ Evaluation criteria } & \multicolumn{2}{|c|}{$\begin{array}{l}\text { Regression estimates } \\
(\mathrm{MJ} \text { of } \mathrm{NE} / \mathrm{d})\end{array}$} \\
\hline & & $\mathrm{MSPE}^{1}$ & $\mathrm{ECT}^{2}$ & $\mathrm{ECT}_{\text {ext }}{ }^{3}$ & $\mathrm{ER}^{4}$ & $\mathrm{ED}^{5}$ & Intercept $(\alpha)$ & Slope $(\beta)$ \\
\hline $\begin{array}{l}\text { Across experiments } \\
\text { NEI }\end{array}$ & 80 & 124 & 5.15 & & 13.5 & 105 & $2.27^{6}$ & $-0.19^{* * 6}$ \\
\hline $\begin{array}{l}\text { Within experiments } \\
\text { NEI }\end{array}$ & 80 & 124 & 3.43 & 97.2 & 11.0 & 12.2 & $1.85^{7}$ & $-0.11^{7}$ \\
\hline $\begin{array}{l}{ }^{1} \text { Mean square predict } \\
{ }^{2} \text { Error due to central } \\
{ }^{3} \text { Error due to central } \\
{ }^{4} \text { Error due to regress } \\
{ }^{5} \text { Error due to disturb } \\
6 \text { The regression estim } \\
\left.- \text { mean }\left(\mathrm{NEI}_{\text {pred }}\right)\right] \text { wh } \\
{ }^{7} \text { The regression estim } \\
\left.-\mathrm{NEI}_{i, \text { pred }}\right)=\alpha+\mathrm{H} \\
\text { due to experiment } i \text {, } \\
{ }^{* *} P<0.01\end{array}$ & $\begin{array}{l}\text { dency } \\
\text { dency }\end{array}$ & $\begin{array}{l}\text { MSPE; B } \\
\text { in individ } \\
\text { trieved fr } \\
\text { bserved, } \\
\text { trieved fr } \\
\beta \times[\mathrm{NE}] \\
\text { he error. }\end{array}$ & $\begin{array}{l}\mathrm{m} \text { simp } \\
\text { red }=\mathrm{p} \\
\mathrm{m} \text { mixe } \\
\text { pred }-\mathrm{m}\end{array}$ & $\begin{array}{l}\text { Toutenbe } \\
\text { ments. } \\
\text { linear m } \\
\text { edicted, } i \\
\text { linear mo } \\
\text { an }\left(\mathrm{NEI}_{p r e}\right.\end{array}$ & $\begin{array}{l} \\
\\
\text { leling: } \\
1, \ldots \\
\text { eling }\end{array}$ & $\begin{array}{l}\mathrm{NEI}_{i, o b} \\
80 \text { trea } \\
\text { th ran } \\
\text { here E }\end{array}$ & $\begin{array}{l}\left.\mathrm{NEI}_{i, \text { pred }}\right)=\alpha+ \\
\text { nt means. } \\
\text { effect of experi } \\
\left.p_{i}\right)=\text { is the ran }\end{array}$ & $\begin{array}{l}\times\left[\left(\mathrm{NEI}_{i, p r e}\right.\right. \\
\text { ent: }\left(\mathrm{NEI}_{i, o b s} \text { s }\right. \\
\text { om intercept }\end{array}$ \\
\hline
\end{tabular}




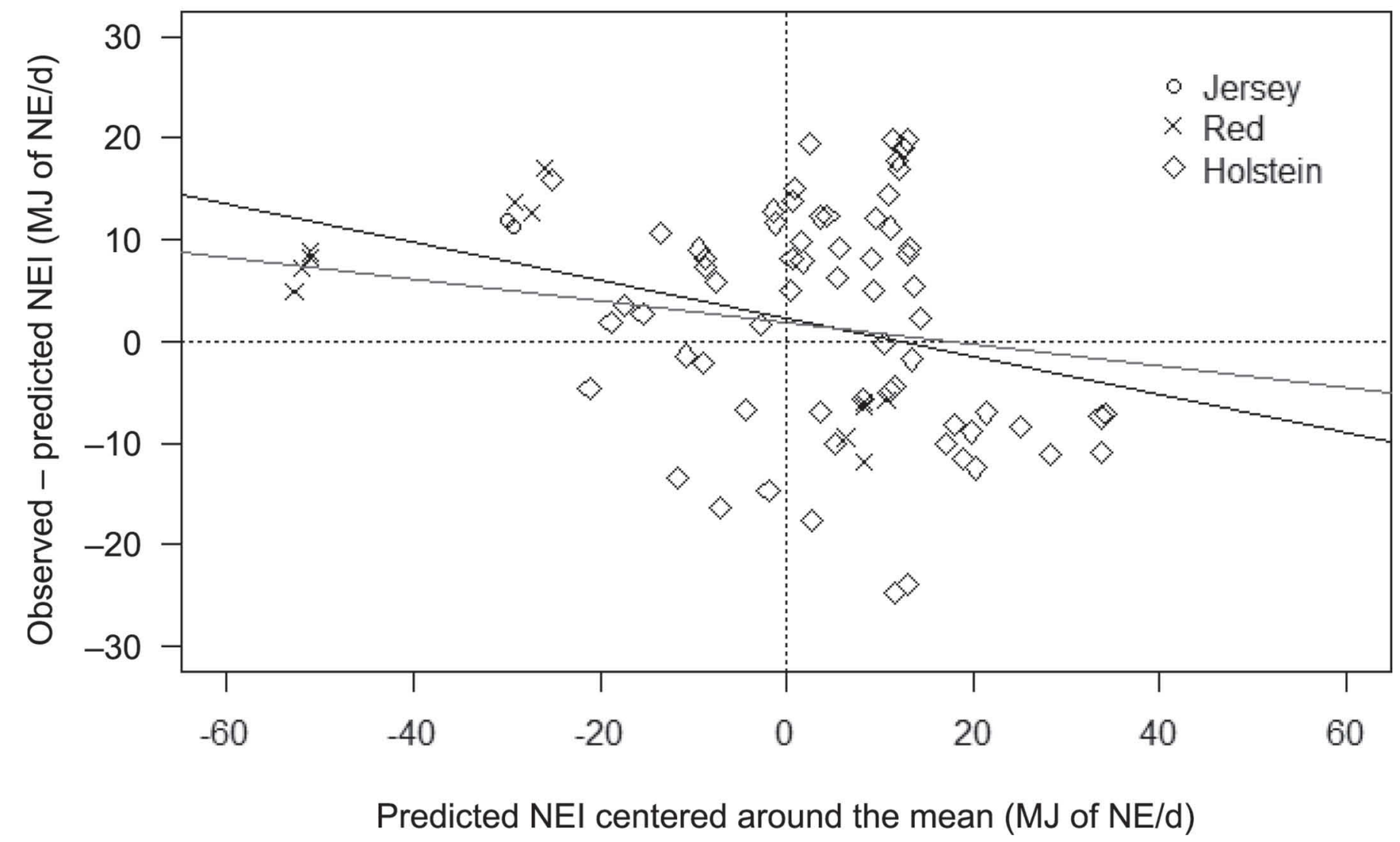

Figure 3. Centralized residual plots of the net energy intake (NEI) model evaluated on 80 treatment means from dairy cows of different breeds fed different diets. Error of regression (ER) is the deviation of the slope from zero; the smaller the ER, the better prediction at both low and high NEI. The black line corresponds to simple linear regression across experiments, whereas the gray line corresponds to mixed linear regression with random effect of experiment, evaluating performance within experiments.

The model predicted differences of NEI between diets within experiments better than differences of NEI across experiments (Table 9). The NEI model demonstrated a small over prediction (Figure 3 ) for the within-experiment analysis (gray line) than the acrossexperiment analysis (black line).

\section{Accuracy of Predicted NEI Evaluated Within Experiments}

Results of the evaluation of the intake model within the 19 experiments are presented as statistical criteria and regression estimates in Table 9. The gray regression line in Figure 3 corresponds to the estimates from the within-experiment analysis of residual NEI of the model.

Evaluating the distribution of error while taking the effect of experiment into consideration, by decomposing ECT into ECT and $\mathrm{ECT}_{\exp }$ (as described in equation
16), makes it possible to evaluate the prediction difference between diets within the 19 experiments. For the model, error was relocated when within-experiment differences between diets were predicted (Table 9). This resulted in a decrease of error located in ED, expressed as a percentage of MSPE, which were $9.9 \%$. The fixed part of ECT was $2.8 \%$ of MSPE, whereas the $\mathrm{ECT}_{\text {exp }}$ was $78.5 \%$ of MSPE for the NEI model. The error located in ER was somewhat affected by the inclusion of experiment as a random factor in the model and resulted in $8.9 \%$ of MSPE.

\section{Residual NEI in Relation to Animal and Dietary Characteristics}

The residual NEI values retrieved from prediction with the NEI model demonstrated no significant relations to ECM $(P=0.17)$, BW $(P=0.93)$, and the proportion of primiparous cows in the treatment groups. 
Table 10. The effect of daily ECM yield, BW, and corrected chewing index $\left(\mathrm{CI}_{\mathrm{NE}}\right)$ on the residual net energy intake (NEI) (observed - predicted) analyzed by simple linear regression with experiment as a random variable

\begin{tabular}{|c|c|c|c|c|c|c|}
\hline \multirow[b]{2}{*}{ Effect of models } & \multicolumn{2}{|c|}{ ECM (kg) } & \multicolumn{2}{|c|}{ BW (kg) } & \multicolumn{2}{|c|}{$\mathrm{CI}_{\mathrm{NE}}(\min / \mathrm{MJ}$ of $\mathrm{NE})$} \\
\hline & Intercept & Slope & Intercept & Slope & Intercept & Slope \\
\hline NEI (MJ of NE/d) & 9.99 & -0.25 & 3.99 & $-3 \times 16^{-3}$ & -9.03 & $1.98^{*}$ \\
\hline
\end{tabular}

The residual NEI retrieved from the NEI model were significantly related to the $\mathrm{CI}_{\mathrm{NE}}$ values of the diets $(P$ $=0.03)$. A significantly positive relationship between residual $\mathrm{NEI}$ and $\mathrm{CI}_{\mathrm{NE}}$ resulted in an increasing underprediction of NEI with increasing $\mathrm{CI}_{\mathrm{NE}}$ (Table 10). The residual NEI retrieved from the NEI model were not significantly related to the concentration of $\mathrm{NDF}_{\mathrm{f}}(P>$ $0.05)$ or $\mathrm{CP}(P=0.49)$ in the diets.

The relation between residual NEI and observed ECM describes how well the model reflects the relation between MY and NEI. In the present evaluation the NEI model shows no relation between ECM and the residual NEI, indicating that the model has succeeded in describing the milk yield variation. The same was seen for $\mathrm{BW}$, with no relation between $\mathrm{BW}$ and residual NEI, even though several breeds of the evaluation data were different from the developmental data.

The residual NEI values were positively related to the $\mathrm{CI}_{\mathrm{NE}}$ values, which imply an increasing underprediction with increasing $\mathrm{CI}_{\mathrm{NE}}$ values above the mean $\mathrm{CI}_{\mathrm{NE}}$ value and increasing overprediction of NEI at decreasing $\mathrm{CI}_{\mathrm{NE}}$ values below the mean $\mathrm{CI}_{\mathrm{NE}}$ value. In addition, residual NEI showed a positive relation with the concentration of $\mathrm{NDF}_{\mathrm{f}}$ per BW (results not shown), which is the primary variable affecting the correction of the dietary $\mathrm{CI}_{\mathrm{NE}}$ value, demonstrating increasing underprediction of NEI with increasing $\mathrm{NDF}_{\mathrm{f}}$ intake.

\section{Forage-to-Concentrate Energy Substitution Rate}

The implication of the negative linear relationship between NEI and $\mathrm{CI}_{\mathrm{NE}}$ is mathematically illustrated in a simplified model for prediction of the forage $\left(\mathrm{NEI}_{\mathrm{f}}\right)$, which depends on the $\mathrm{NEI}_{0}$ and the supplementation of concentrate $\left(\mathrm{NEI}_{\mathrm{c}}\right.$; equation 13). Figure 4 illustrates the theoretical marginal effect of increasing $\mathrm{NEI}_{\mathrm{c}}$ supplementation on the ad libitum intake of $\mathrm{NEI}_{\mathrm{f}}$ by assuming the NEI model is valid, and equation 13 is based on no major interactions between the NE value of forage and concentrates. The forage-to-concentrate energy substitution rate, which is the change in forage intake when the amount of concentrate is increased in the diet, can be estimated as the change in $\mathrm{NEI}_{\mathrm{f}}$ with changing $\mathrm{NEI}_{c}$, as a function of $\mathrm{CI}_{\mathrm{f}}, \mathrm{CI}_{\mathrm{c}}, \mathrm{CT}_{\max }$, and $\mathrm{NEI}_{0}$ (equation 13). Figure 4 illustrates the estimated substitution rates associated with increasing $\mathrm{NEI}_{c}$, decreasing $\mathrm{NEI}_{0}$, and decreasing $\mathrm{CI}_{\mathrm{f}}$.

Figure 4 demonstrates that the predicted decrease in forage intake per unit of added concentrate increases with increasing concentrate supplementation in 4 different combinations of forage with high and low $\mathrm{CI}_{\mathrm{f}}$, 16 and $8 \mathrm{~min} / \mathrm{MJ}$ of $\mathrm{NE}$, respectively, combined with high $\left(\mathrm{NEI}_{0}=200 \mathrm{MJ}\right.$ of $\left.\mathrm{NE} / \mathrm{d}\right)$ and low $\left(\mathrm{NEI}_{0}=100\right.$ MJ of NE/d) energy intake capacity (equation 13). Increasing concentrate supplementation results in lower forage intake and, consequently, lower dietary $\mathrm{CI}_{\mathrm{NE}}$ values, which decline toward the absolute minimum chewing time to ensure healthy rumen at the right endpoints of the 4 curves. The marginal decrease in forage intake per unit of extra concentrate is less in cows with a high $\mathrm{NEI}_{0}$ than in those with a low $\mathrm{NEI}_{0}$ (solid vs. dashed lines). Feeding low digestible forage with high $\mathrm{CI}_{\mathrm{f}}$ results in a smaller marginal decrease in forage intake per unit of extra concentrate compared with high digestible forage of low $\mathrm{CI}_{\mathrm{f}}$ (thin vs. thick lines). If the $\mathrm{NEI}_{0}$ of the cow and forage digestibility are combined, the marginal decrease in forage intake per extra unit of concentrate is lower in cows with high $\mathrm{NEI}_{0}$ fed low digestible forage of high $\mathrm{CI}_{\mathrm{f}}$ than in cows with low $\mathrm{NEI}_{0}$ fed highly digestible forage of lower $\mathrm{CI}_{\mathrm{f}}$. Equation 13 predicts a substitution rate to approach -0.2 at zero concentrate allocation for the combination of either high $\mathrm{NEI}_{0}$ with low $\mathrm{CI}_{\mathrm{f}}$ or low $\mathrm{NEI}_{0}$ with high $\mathrm{CI}_{\mathrm{f}}$ values, indicating mainly a physically constrained intake at these combinations of forage and animal characteristics. A substitution rate of approximately -0.7 with zero concentrate supplementation to cows with a low $\mathrm{NEI}_{0}$ (100 MJ of NE/d) fed high-quality forage $\left(\mathrm{CI}_{\mathrm{f}}=8 \mathrm{~min} / \mathrm{MJ}\right.$ of $\left.\mathrm{NE}\right)$ indicates that the intake is partly metabolically constrained even when cows are fed forage only. In addition, the model is theoretically considered to be valid for NEI $>1 / 2 \mathrm{NEI}_{0}$; accordingly, cows with a high $\mathrm{NEI}_{0}(200 \mathrm{MJ}$ of NE/d) fed a low digestible forage $\left(\mathrm{CI}_{\mathrm{f}}=16 \mathrm{~min} / \mathrm{MJ} \mathrm{NE}\right.$; thin line $)$ require a minimum concentrate supplementation of $50 \mathrm{MJ}$ of $\mathrm{NEI}_{\mathrm{c}} / \mathrm{d}$ to obtain a total intake of $1 / 2 \times \mathrm{NEI}_{0}$, based on equation 5 and 11 in combination with a $\mathrm{CT}_{\max }$ value of $819 \mathrm{~min} / \mathrm{d}$. Consequently, intake is considered to be physically constrained with a substitution rate close to zero for concentrate supplementation below $50 \mathrm{MJ}$ of 
$\mathrm{NEI}_{\mathrm{c}}$ /d (for cows with a $\mathrm{NEI}_{0}$ of $200 \mathrm{MJ}$ of $\mathrm{NE} / \mathrm{d}$ ) fed a low digestible forage $\left(\mathrm{CI}_{\mathrm{f}}=16 \mathrm{~min} / \mathrm{MJ}\right.$ of $\left.\mathrm{NE}\right)$.

This model demonstrates variable substitution rates depending on the metabolic intake capacity $\left(\mathrm{NEI}_{0}\right)$, level of $\mathrm{NEI}_{c}$, and forage quality represented by the $\mathrm{CI}_{\mathrm{f}}$ value, which is in agreement with principles behind the intake model by Faverdin et al. (2011). This implies that the substitution rate depends on both animal characteristics, such as $\mathrm{NEI}_{0}$, the energy balance and dietary characteristics such as the $\mathrm{CI}_{\mathrm{NE}}$ value. Increasing supplementation generally increases NEI, milk yield, and energy balance. Faverdin et al. (1991) described the relationship between substitution rate and difference in milk production in association with energy balance and showed an increasing substitution with increasing energy balance; this was in accordance with the findings of the present study, where $\mathrm{NEI}_{0}$ decreases with increasing DIM and thereby decreased milk yield, resulting in an increasing substitution.

The variable substitution rate in the present model is to some extent similar to the INRA intake model (Faverdin et al., 2011) and the TDMI model (Huhtanen et al., 2011), where both depend directly on the amount of concentrate in the diet; however, they are quite different from intake models described by Gruber et al. (2004) and Zom et al. (2012), who described models with no direct effect or a constant effect of concentrate on substitution rate. Feeding diets with $\mathrm{CI}_{\mathrm{NE}}$ values higher than $2 \times \mathrm{CT}_{\max } / \mathrm{NEI}_{0}$ lead to physical constraints and the maximum daily chewing time limits intake. The inclusion of $\mathrm{NEI}_{0}$ in the substitution rate introduces production characteristics, such as stage of lactation or DIM and milk yield, directly into the substitution rate. Days in milk is a time variable that can be used to describe the change in nutrient demand for milk production over the lactation period (Conrad et al., 1964), and relates the substitution rate to time through the $\mathrm{NEI}_{0}$ variable.

\section{Model Limitations}

The NEI model was developed, parameterized, and validated by use of intake data from barn-fed lactating dairy cows from 25 to 275 DIM, and the model estimation of the $\mathrm{NEI}_{0}$ value most likely led to overprediction of NEI in very early lactation and underprediction of NEI of low-yielding cows in late lactation and in dry cows due to slope bias expressed by the model. The linear NEI model is theoretically considered to be valid for rations where feed intake is considered to be both physically and metabolically constrained. This implies that the NEI should be higher than $1 / 2 \times \mathrm{NEI}_{0}$, which we consider to reflect the borderline for full physical constraint of intake. The daily $\mathrm{CT}$ is considered to

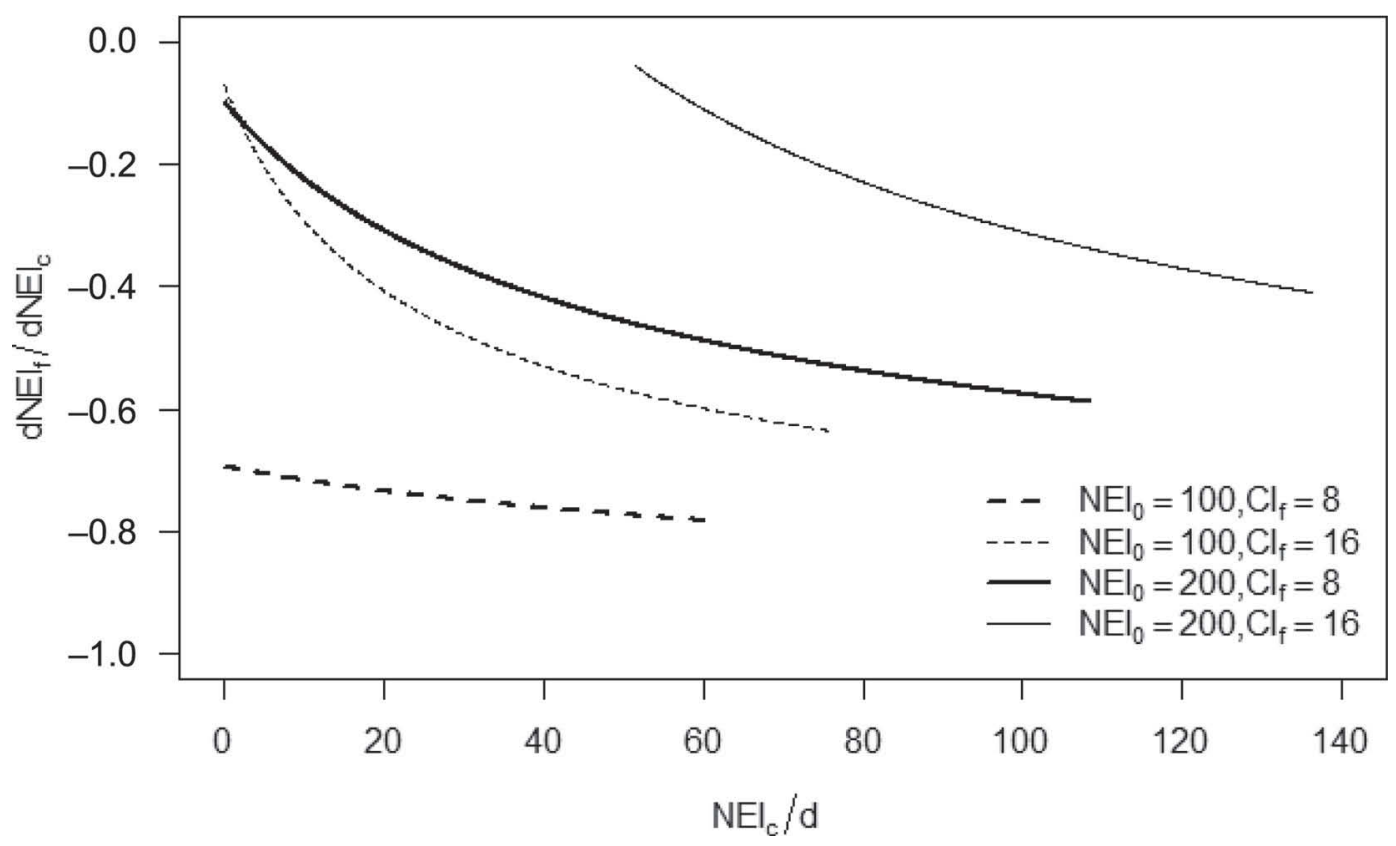

Figure 4. Forage-to-concentrate substitution rate expressed as the nonlinear decrease in net energy intake from forage (NEI $)_{f}$ as a function of increasing net energy intake from concentrate $\left(\mathrm{NEI}_{\mathrm{c}}\right)$, presented by 2 hypothetical cows with different intake capacities $\left(\mathrm{NEI}_{0}=200 \mathrm{MJ}\right.$ of $\mathrm{NE} / \mathrm{d}$, solid; and $\mathrm{NEI}_{0}=100 \mathrm{MJ}$ of $\mathrm{NE} / \mathrm{d}$, dashed) and a maximum daily chewing time of 819 min, fed 2 different forage qualities $\left(\mathrm{CI}_{\mathrm{f}}=8\right.$ min/ MJ of NE, thick; and $\mathrm{CI}_{\mathrm{f}}=16 \mathrm{~min} / \mathrm{MJ}$ of $\mathrm{NE}$, thin). The endpoints to the right of the 4 curves represent diets with chewing index values of 3 min/MJ of net energy, showing no diets with chewing index (CI) values lower than the NorFor minimum (Nørgaard et al., 2011). 
approach $\mathrm{CT}_{\max }$ at physical constraint on intake. Furthermore, the validity of the NEI model is based on the assumption that neither rumen disorders, palatability of the feed, intake of metabolizable protein, or other nutrients constrain intake. In the present study, only 7 of 136 dietary treatments had a concentration of $\mathrm{NDF}_{\mathrm{f}}$ below $16 \%$ of DM, which may lead to rumen $\mathrm{pH}$ below 5.9 according to a meta-analysis by Zebeli et al. (2008). The NorFor recommends a general minimum $\mathrm{CI}_{\mathrm{DM}}$ of $30 \mathrm{~min} / \mathrm{kg}$ of DM for the prevention of rumen disorders (Nørgaard et al., 2011), which corresponds to about $3.8 \mathrm{~min} / \mathrm{MJ}$ of NE. Five dietary treatments had a $\mathrm{CI}_{\mathrm{NE}}$ value of 3.2 to $3.8 \mathrm{~min} / \mathrm{MJ}$ of NE. The lowest NEI observed in any of the 136 treatment means, shown in Figure 1, was $42 \%$ of the predicted energy intake capacity $\left(\mathrm{NEI}_{0, \text { fixed }}+\mathrm{NEI}_{0, i}+\mathrm{NEI}_{0, j}\right)$. A total of $4 \%$ of the treatment means had a numeric NEI value below half of the predicted $\mathrm{NEI}_{0}$ value. The location of 6 treatment means outside the linear range of the model could indicate a physical limitation on NEI by the $\mathrm{CI}_{\mathrm{NE}}$ value of the diet. The 6 outlying treatment means are part of a larger experiment including a total of 16 treatment means. When observations with NEI values below the predicted value of $1 / 2 \times \mathrm{NEI}_{0}$ are included, we would expect a worse model fit. Thus, when the model still seems sufficient and accurate after inclusion of these observations is in favor for the model. Finally, there is uncertainty in the prediction of $1 / 2 \times \mathrm{NEI}_{0}$, and we can first judge whether the observed values are below $\mathrm{NEI}_{0}$ after the analysis has been done.

The $\mathrm{CI}_{\mathrm{NE}}$ values used in our study were corrected for intake of $\mathrm{NDF}_{\mathrm{f}}$ in relation to $\mathrm{BW}$ different from the NorFor standard of $0.007 \mathrm{~kg} / \mathrm{kg}$, which is the typical intake of $\mathrm{NDF}_{\mathrm{f}}$ in optimal diets in commercial dairy herds in Scandinavia; consequently, the NEI close to normal optimal diet can be predicted without correction for $\mathrm{CI}_{\mathrm{NE}}$ for deviant $\mathrm{NDF}_{\mathrm{f}}$ intake. However, a low concentrate supplementation leads to a higher intake of $\mathrm{NDF}_{\mathrm{f}}$ per $\mathrm{BW}$ and a lower mean chewing time per $\mathrm{NDF}_{\mathrm{f}}$ compared with the ones used for the NorFor standard $\mathrm{CI}_{\mathrm{DM}}$ values. Consequently, the NEI would be underestimated without using the corrected $\mathrm{CI}_{\mathrm{NE}}$ values. However, as the prediction of NEI is a linear function of the $\mathrm{CI}_{\mathrm{NE}}$, the prediction of $\mathrm{NDF}_{\mathrm{f}}$ per $\mathrm{BW}$ can be done by iteration.

\section{CONCLUSIONS}

Our study supports a negative linear relationship between NEI and the corrected $\mathrm{CI}_{\mathrm{NE}}$, with slope values in direct proportion with the squared intercepts $\left(\mathrm{NEI}_{0}\right)$ from the individual experiments. The $\mathrm{NEI}_{0}$ values are considered as the metabolic net energy intake capacity of a specific group of cows, which can be estimated from $\mathrm{BW}^{0.75}$, DIM, and milk yield. The validation of the NEI model predicted a daily NEI with an RMSPE value of $11 \mathrm{MJ}$ of $\mathrm{NE} / \mathrm{d}(8.0 \%)$, mostly as random error. The NEI model slightly overpredicted high intakes and underpredicted at low intakes when predicting differences in NEI both between diets within and across experiments. The NEI model implies a variable forageto-concentrate substitution rate depending on the $\mathrm{NEI}_{0}$ value of the group of cows, concentrate intake, and dietary chewing index of the forage.

\section{ACKNOWLEDGMENTS}

The authors acknowledge Mette Vestergaard Nielsen (University of Copenhagen) for all her help throughout the writing process. This research was co-funded by an EU interreg project (REKS 4), Danish Cattle Federation, The Danish AgriFish Agency, Ministry of Environment and Food, and the Department of Veterinary Clinical and Animal Science, University of Copenhagen, Denmark. All data were kindly lent to us by the NorFor group (NorFor amba, Aarhus, Denmark).

\section{REFERENCES}

Aaes, O. 1993. Fuldfoder kontra separat tildeling af energirige foderrationer udfodret efter ædelyst eller restriktivt til malkekøer. Forskningsrapport nr. 16. Statens Husdyrbrugsforsøg. Foulum. Denmark. 22 pp.

Åkerlind, M., N. I. Nielsen, and H. Volden. 2011. Animal input characteristics. Pages 27-32 in The Nordic Feed Evaluation System 2011. H. Volden, ed. Wageningen Academic Publishers, Wageningen, the Netherlands.

Allen, M. S. 1996. Physical constraints on voluntary intake of forages by ruminants. J. Anim. Sci. 74:3063-3075.

Allen, M. S. 2000. Effects of diet on short-term regulation of feed intake by lactating dairy cattle. J. Dairy Sci. 83:1598-1624.

Alstrup, L., K. Søegaard, and M. R. Weisbjerg. 2016. Effect of maturity and harvest season of grass-clover silage and of forage-toconcentrate ratio on milk production of dairy cows. J. Dairy Sci. 99:328-340. http://dx.doi.org/10.3168/jds.2015-9802.

Alstrup, L., K. Søegaard, and M. R. Weisbjerg. 2016. Effect of maturity and harvest season of grass-clover silage and of forage-to-concentrate ratio on milk production of dairy cows with some text to force a break. J. Dairy Sci. 99:328-340. http://dx.doi.org/10.3168/ jds.2015-9802.

ARC. 1980. The Nutrient Requirements of Ruminant Livestock. Slough, Commonwealth Agricultural Bureaux, Slough, UK.

Armentano, L. E., S. J. Bertics, and G. A. Ducharme. 1997. Response of lactating cows to methionine or methionine plus lysine added to high protein diets based on alfalfa and heated soybeans. J. Dairy Sci. 80:1194-1199.

Balch, C. C. 1971. Proposal to use time spent chewing as an index of the extent to which diets for ruminants possess the physical property of fibrousness characteristic of roughages. Br. J. Nutr. 26:383-392.

Bateman, H. G., J. N. Spain, M. S. Kerley, R. L. Belyea, and R. T. Marshall. 1999. Evaluation of ruminally protected methionine and lysine or blood meal and fish meal as protein sources for lactating Holsteins. J. Dairy Sci. 82:2115-2120.

Bibby, J., and H. Toutenberg. 1977. Prediction and Improvement Estimation in Linear Models. John Wiley, London, UK. 
Bossen, D., and M. R. Weisbjerg. 2009. Allocation of feed based on individual dairy cow live weight changes: II: Effect on milk production. Livest. Sci. 126:273-285.

Bossen, D., M. R. Weisbjerg, L. Munksgaard, and S. Højsgaard. 2009. Allocation of feed based on individual dairy cow live weight changes: I: Feed intake and live weight changes during lactation. Livest. Sci. 126:252-272.

Bremmer, D. R., T. R. Overton, and J. H. Clark. 1997. Production and composition of milk from Jersey cows administered bovine somatotropin and fed ruminally protected amino acids. J. Dairy Sci. 80:1374-1380

Casper, D. P., and D. J. Schingoethe. 1988. Protected methionine supplementation to a barley-based diet for cows during early lactation. J. Dairy Sci. 71:164-172

Conrad, H. R., A. D. Pratt, and J. W. Hibbs. 1964. Regulation of feed intake in dairy cows. 1. Change in importance of physical and physiological factors with increasing digestibility. J. Dairy Sci. 47:54-62.

Demment, M. W., and P. J. Van Soest. 1985. A nutritional explanation for body-size patterns of ruminant and nonruminant herbivores. Am. Nat. 125:641-672.

Eriksson, T., M. Murphy, P. Ciszuk, and E. Burstedt. 2004. Nitrogen balance, microbial protein production, and milk production in dairy cows fed fodder beets and potatoes, or barley. J. Dairy Sci. 87:1057-1070

Faverdin, P. 1992. Alimentation des vaches laitères: Comparaison des différentes méthodes de prédiction des quantités ingérées. INRA Production Animales 5:271-282.

Faverdin, P., C. Baratte, R. Delagarde, and J. L. Peyraud. 2011. GrazeIn: A model of herbage intake and milk production for grazing dairy cows. 1. Prediction of intake capacity, voluntary intake and milk production during lactation. Grass Forage Sci. 66:29-44.

Faverdin, P., J. P. Dulphy, J. B. Coulon, R. Vérité, J. P. Garel, and J. Rouel. 1991. Substitution of roughage by concentrates for dairy cows. Livest. Prod. Sci. 27:137-156.

Friggens, N. C., G. C. Emmans, I. Kyriazakis, J. D. Oldham, and M. Lewis. 1998. Feed intake relative to stage of lactation for dairy cows consuming total mixed diets with a high or low ratio of concentrate to forage. J. Dairy Sci. 81:2228-2239.

Friggens, N., G. C. Emmans, S. Robertson, D. G. Chamberlain, C. T. Whittemore, and J. D. Oldham. 1995. The lactational responses of dairy cows to amount of feed and to the source of carbohydrate energy. J. Dairy Sci. 78:1734-1744.

Fuentes-Pila, J., M. A. DeLorenzo, D. K. Beede, C. R. Staples, and J. B. Holter. 1996. Evaluation of equations based on animal factors to predict intake of lactating Holstein cows. J. Dairy Sci. $79: 1562-1571$

Gruber, L., F. J. Schwarz, D. Erdin, B. Fischer, H. Spiekers, H. Steingass, U. Meyer, A. Chassot, T. Jilg, A. Omermaier, and T. Gruggenberg. 2004. Vorhersage der Futteraufnahme von MilchkühenDatenbasis von 10 forschungs- und universitätsinstituten Deutchlands, Österreichs and der Schweiz. 116. VDLUFA-Kongress, Sep. 13-17, 2004, Rostock, Germany. Kongressband 2004:484-504

Huhtanen, P., M. Rinne, P. Mantysaari, and J. Nousiainen. 2011. Integration of the effects of animal and dietary factors on total dry matter intake of dairy cows fed silage-based diets. Animal 5:691-702.

Huhtanen, P., M. Rinne, and J. Nousiainen. 2007. Evaluation of the factors affecting silage intake of dairy cows: A revision of the relative silage dry-matter intake index. Animal 1:758-770.

Ingvartsen, C. L. 1994. Models of voluntary food intake in cattle. Livest. Prod. Sci. 39:19-38.

Ingvartsen, K. L., O. Aaes, and J. B. Andersen. 2001. Effects of pattern of concentrate allocation in the dry period and early lactation on feed intake and lactational performance in dairy cows. Livest. Prod. Sci. 71:207-221.

Jensen, C., S. Østergaard, I. Schei, J. Bertilsson, and M. R. Weisbjerg. 2015b. A meta-analysis of milk production responses to increased net energy intake in Scandinavian dairy cows. Livest. Sci. 175:59-69.
Jensen, L. M. 2015. Prediction of feed intake by dairy cows-Development of a new net energy intake model. PhD thesis. Faculty of Health, Department of Veterinary Clinical and Animal Sciences, University of Copenhagen, Copenhagen, Denmark.

Jensen, L. M., N. I. Nielsen, E. Nadeau, B. Markussen, and P. Nørgaard. 2015a. Evaluation of five models predicting feed intake by dairy cows fed total mixed rations. J. Livest. Sci. 176:91-103.

Keady, T. W. J., C. S. Mayne, and D. J. Klipatrick. 2004. An evaluation of five models commonly used to predict food intake of lactating dairy cattle. Livest. Prod. Sci. 89:129-138.

Kertz, A. F., L. F. Reutzel, and G. M. Thomson. 1991. Dry matter intake from parturition to midlactation. J. Dairy Sci. 74:2290-2295.

Kristensen, T., and M. R. Weisbjerg. 2008. Lucerneensilage til malkekøer-Resultater af fodringsfors $\varnothing \mathrm{g}$ og perspektiver for inddragelse i foderforsyningen. Pages 5-12 in Fodringsdag-Temadag om Aktuelle Fodringsspørgsmål. Dansk Kvæg, Aarhus, Denmark.

Kristensen, V. F. 1999. Grovfoderkildens betydning for malkekoens produktion og fodereffektivitet. Temamøde malkekøernes og kviernes ernæring. Statens Husdyrbrugsfors $\varnothing \mathrm{g}$ rapport 118. Frederiksberg bogtrykkeri, Frederiksberg, Denmark, pp. 18-33.

Krizsan, S. J., A. Höjer, A. Huuskonen, M. Hetta, and P. Huhtanen. 2014. Evaluation of the feed intake model in the Nordic feed evaluation system NorFor. Acta Agric. Scand. A Anim. Sci. 64:110-122.

Leonardi, C., M. Stevenson, and L. E. Armentano. 2003. Effect of two levels of crude protein and methionine supplementation on performance of dairy cows. J. Dairy Sci. 86:4033-4042.

Løvendahl, P., C. Ridder, and N. C. Friggens. 2010. Limits to prediction of energy balance from milk composition measures at individual cow level. J. Dairy Sci. 93:1998-2006.

Lund, P. 2002. The effect of forage type on passage kinetics and digestibility of fiber in dairy cows. PhD thesis. Department of Animal Science and Animal Health, The Royal Veterinary and Agricultural University, Copenhagen, Denmark.

Mertens, D. R. 1987. Predicting intake and digestibility using mathematical models of ruminal function. J. Anim. Sci. 64:1548-1558.

Mertens, D. R. 1994. Regulation of forage intake. Pages 450-493 in Forage Quality, Evaluation, and Utilization. G. C. Fahey, M. Collins, Jr, D. R. Mertens, and L. E. Moser, ed. ASA, CSSA, SSA, Madison, WI.

Mertens, D. R. 2007. Digestibility and intake. Pages 487-507 in The Science of Grassland Agriculture Forages. R. F. Barnes, C. J. Nelson, K. J. Moore, and M.Collins, ed. Blackwell Publ., Ames, IA.

Mogensen, L., and T. Kristensen. 2002. Effect of barley or rape seed cake as supplement to silage for high-yielding organic dairy cows. Acta Agric. Scand. A Anim. Sci. 52:243-252.

Mogensen, L., P. Lund, T. Kristensen, and M. R. Weisbjerg. 2008. Effects of toasting blue lupins, soybeans or barley as supplement for high-yielding, organic dairy cows fed grass-clover silage ad libitum. Livest. Sci. 115:249-257.

Nielsen, N. I., N. C. Friggens, T. Larsen, J. B. Andersen, M. O. Nielsen, and K. L. Ingvartsen. 2007. Effect of changes in diet energy density on feed intake, milk yield and metabolic parameters in dairy cows in early lactation. Animal 1:335-346.

Nielsen, N. I., and H. Volden. 2011. Animal requirements and recommendations. Pages 85-112 in The Nordic Feed Evaluation System 2011. H. Volden, ed. Wageningen Academic Publishers, Wageningen, the Netherlands.

NorFor. 2010. Feedstuff table. Accessed Mar. 22, 2010. http:// feedstuffs.norfor.info/.

NorFor. 2010. Feedstuff table. Accessed Mar., 2010. http://feedstuffs. norfor.info/.

Nørgaard, P. 1986. Physical structure of feeds for dairy cows. Page 85 in New Developments and Future Perspectives in Research on Rumen Function. A. Neimann-Sorensen, ed. Comm. Eur. Commun., Luxembourg, Luxembourg.

Nørgaard, P. 1989. Influence of the physical form of diet on chewing activity and reticulo-rumen motility in lactating cows. Acta Agric Scand. 39:187-202.

Nørgaard, P., and L. Mølbak. 2001. Relation between dietary chewing index and net energy intake in cattle fed concentrates restrictively 
and forage ad libitum. Pages 67-70 in Energy Metabolism in Animals. Proceedings of the 15th Symposium on Energy Metabolism in Animals. Snekkersten, Denmark. A. Chwalibog, and K. Jakobsen, ed. EAAP publication, no 103, Wageningen, the Netherlands.

Nørgaard, P., E. Nadeau, Å. Randby, and H. Volden. 2011. Chewing index system for predicting physical structure of the diet. Pages 127-132 in The Nordic Feed Evaluation System 2011. H. Volden, ed. Wageningen Academic Publishers, Wageningen, the Netherlands.

Nørgaard, P., E. Nadeau, and A. T. Randby. 2010. A new Nordic structure evaluation system for diets fed to dairy cows: A metaanalysis. Pages 112-120 in Modelling Nutrient Digestion and Utilisation in Farm Animals. D. Sauvant, J. Van Milgen, P. Faverdin, and N. Friggens, ed. Wageningen Academic Publishers, Wageningen, the Netherlands.

NRC. 2001. Nutrient Requirements of Dairy Cattle. 7th rev. ed. Natl. Acad. Press, Washington, DC.

Ordway, R. S., S. E. Boucher, N. L. Whitehouse, C. G. Schwab, and B. K. Sloan. 2009. Effects of providing two forms of supplemental methionine to periparturient Holstein dairy cows on feed intake and lactational performance. J. Dairy Sci. 92:5154-5166.

Overton, T. R., L. S. Emmert, and J. H. Clark. 1998. Effects of source of carbohydrate and protein and rumen-protected methionine on performance of cows. J. Dairy Sci. 81:221-228.

Piepenbrink, M. S., T. R. Overton, and J. H. Clark. 1996. Response of cows fed a low crude protein diet to ruminally protected methionine and lysine. J. Dairy Sci. 79:1638-1646.

Pisulewski, P. M., and Z. M. Kowalski. 1999. The effect of protected methionine on milk yield and its composition in lactating dairy cows fed grass silage-based diets. J. Anim. Feed Sci. 8:355-366.

Prestløkken, E., A. T. Randby, M. Eknæs, and T. H. Garmo. 2008. Effect of harvesting time and wilting on feed intake and milk production. Grassl. Sci. Eur. 13:849-851.

Randby, Å.T. 2003. Høstetid og fôrkvalitet. Kvithamarmøtet, Planteforsk. Grønn kunnskap 7, pp. 27-43. Planteforsk, Ås, Norway.

Randby, A. T., M. R. Weisbjerg, P. Nørgaard, and B. Heringstad. 2012. Early lactation feed intake and milk yield responses of dairy cows offered grass silages harvested at early maturity stages. J. Dairy Sci. 95:304-317.

Rinne, M., S. Jaakkola, K. Kaustell, T. Heikkilä, and P. Huhtanen. 1999. Silage harvested at different stages of grass growth v. concentrate foods as energy and protein sources in milk production. Anim. Sci. 69:251-263.

Romney, D. L., and M. Gill. 2000. Intake of forages. Pages 43-63 in Forage Evaluation in Ruminant Nutrition. D. I. Givens, E. Owen, R. F. E. Axford, and H. M. Omed, ed. CABI Publishing, Wallingford, UK.

Samuelson, D. J., S. K. Denise, R. Roffler, R. L. Ax, D. V. Armstrong, and D. F. Romagnolo. 2001. Response of Holstein and Brown Swiss cows fed alfalfa hay-based diets to supplemental methionine at two stages of lactation. J. Dairy Sci. 84:917-928.

Schei, I., H. Volden, and L. Bævre. 2005. Effects of energy balance and metabolizable protein level on tissue mobilization and milk performance of dairy cows in early lactation. Livest. Prod. Sci. 95:35-47.
Sjaunja, L. O., L. Baevre, L. Junkkarinen, J. Pedersen, and J. Setälä. 1990. A Nordic proposal for an energy corrected milk (ECM) formula. Pages 156-192 in European Association for Animal Production Publication, Performance Recording of Animals: State of the Art, 1990; 27th Biennial Session of the International Committee for Animal Recording. P. Gaillon and Y. Chabert, ed. Centre for Agricultural Publishing and Documentation, Paris, France.

Soder, K. J., and L. A. Holden. 1999. Lymphocyte proliferation response of lactating dairy cows fed varying concentrations of rumen-protected methionine. J. Dairy Sci. 82:1935-1942.

Thomas, C. 2004. Feed into milk-A new applied feeding system for dairy cows - An advisory manual. Nottingham University Press, Nottingham, UK.

Thuen, E. 1989. Influence of source and level of dietary protein on milk yield, milk composition and some rumen- and blood components in dairy cows. PhD thesis. Department of Animal Science, Agricultural University of Norway, Ås, Norway.

Vadiveloo, J., and W. Holmes. 1979. The prediction of the voluntary feed intake of dairy cows. J. Agric. Sci. (Camb.) 93:553-562.

Volden, H., and N. I. Nielsen. 2011. Energy and metabolizable protein supply. Pages 81-84 in The Nordic Feed Evaluation System 2011. $\mathrm{H}$. Volden, ed. Wageningen Academic Publishers, Wageningen, the Netherlands.

Volden, H., N. I. Nielsen, M. Åkerlind, M. Larsen, Ø. Havrevoll, and A. J. Rygh. 2011. Prediction of voluntary feed intake. Pages 113126 in The Nordic Feed Evaluation System. H. Volden, ed. Wageningen Academic Publishers, Wageningen, the Netherlands.

Wallsten, J., and K. Martinsson. 2009. Effects of maturity stage and feeding strategy of whole crop barley silage on intake, digestibility and milk production in dairy cows. Livest. Sci. 121:155-161.

Weisbjerg, M. R. 2007. Lucerneensilage til malkekøer-Resultat fra nye fors $\varnothing$ g. Pages 3-8 in Fodringsdag-Temadag om Aktuelle Fodringsspørgsmål. Dansk Kvæg, Aarhus, Denmark.

Weisbjerg, M. R., M. K. Larsen, L. Hymøller, M. Thorhauge, U. Kidmose, J. H. Nielsen, and J. B. Andersen. 2013. Milk production and composition in Danish Holstein, Danish Red, and Danish Jersey cows supplemented with saturated or unsaturated fat. Livest. Sci. 155:60-70.

Weisbjerg, M. R., L. Wiking, N. B. Kristensen, and P. Lund. 2008. Effects of supplemental dietary fatty acids on milk yield and fatty acid composition in high and medium yielding cows. J. Dairy Res. $75: 142-152$.

Xu, S., J. H. Harrison, W. Chalupa, C. Sniffen, W. Julien, H. Sato, T. Fujieda, and K. Watanabe. 1998. The effect of ruminal bypass lysine and methionine on milk yield and composition of lactating cows. J. Dairy Sci. 81:1062-1077.

Zebeli, Q., J. Dijkstra, M. Tafaj, H. Steingass, B. N. Ametaj, and W. Drochner. 2008. Modeling the adequacy of dietary fiber in dairy cows based on the responses of ruminal $\mathrm{pH}$ and milk fat production to composition of the diet. J. Dairy Sci. 91:2046-2066.

Zom, R. L. G., G. André, and A. M. van Vuuren. 2012. Development of a model for the prediction of feed intake by dairy cows: 1 . Prediction of feed intake. Livest. Sci. 143:43-57. 